Revista lus et Praxis, Año 18, № 1, 2012, pp. 61 - 112

ISSN 0717 - 2877

Universidad de Talca - Facultad de Ciencias Jurídicas y Sociales

"Estatus del no nacido en la Convención Americana:

un ejercicio de interpretación"

Álvaro Paúl Díaz

\title{
ESTATUS DEL NO NACIDO EN LA CONVENCIÓN AMERICANA: UN EJERCICIO DE INTERPRETACIÓN*
}

\author{
Status OF THE UNBORN IN THE AMERICAN CONVENCION: \\ AN INTERPRETIVE EXERCISE
}

Álvaro Paúl Díaz

\section{RESUMEN}

Este estudio interpreta el ambiguo artículo 4.1 de la Convención Americana sobre

Derechos Humanos, que dispone que el derecho a la vida deberá protegerse, "en general, a partir del momento de la concepción". Al hacerlo, toma en cuenta diversos sistemas de interpretación, y tiene presente lo registrado en los trabajos preparatorios de la Convención. Asimismo, este estudio analiza lo que la Comisión Interamericana ha resuelto en esta materia, evaluando el valor de tales decisiones.

Este artículo concluye que, si bien una de las posibles interpretaciones de la Convención Americana sostiene que ella toleraría ciertas legislaciones nacionales que permitan el aborto en circunstancias excepcionales, ella declara la personalidad del nasciturus.

\section{ABSTRACT}

This study interprets the ambiguous Article 4(1) of the American Convention on Human Rights, which establishes that life shall be protected "in general, from the moment of conception". When doing so, it pays attention to different interpretive systems, and takes into account what is recorded in the travaux préparatoires of the Convention. Likewise, this study analyzes what the Inter-American Commission has determined on this issue, and assesses the value of those decisions. This article concludes that, even though one of the possible interpretations of the American Convention affirms that it would tolerate domestic legislations providing for abortion in exceptional circumstances, it declares the unborn's personhood.

PALABRAS CLAVE

Convención Americana sobre Derechos Humanos, Aborto, Corte Interamericana de Derechos Humanos

KEYWORDS

American Convention on Human Rights, Abortion, Inter-American Court of Human Rights

\footnotetext{
* El autor agradece los comentarios y críticas realizadas por William Binchy y Thomas Finegan. Trabajo recibido el 15 de noviembre de 2011 y aprobado el 20 de abril de 2012.

* Licenciado en Ciencias Jurídicas por la Universidad de los Andes; Abogado; Máster en Derecho (MJur) por la Universidad de Oxford y candidato a Doctor (PhD) en Trinity College Dublin. Correo electrónico: alvaropauldiaz@gmail.com.
} 


\section{INTRODUCCIÓN}

Desapariciones forzadas, ejecuciones extrajudiciales y tortura solían ser los principales casos en los que la Corte Interamericana de Derechos Humanos desarrollaba su jurisprudencia. Hoy en día la Corte se ve enfrentada a violaciones mucho menos patentes, con casos en los que debe analizar asuntos más sutiles y en los que puede existir menos consenso. Ellos incluyen materias como interceptaciones telefónicas, derechos políticos e inmigración ilegal. Hasta el momento la Corte Interamericana ha dictado más de ciento treinta sentencias de fondo sobre los más diversos asuntos, los que abarcan una amplia gama de materias. Entre esta jurisprudencia puede observarse alguna muy novedosa, como aquella que lidia con el derecho de propiedad de comunidades indígenas. Este es el tema principal del reciente caso llamado Comunidad Indígena Xákmok Kásek Vs. Paraguay (caso Xákmok), ${ }^{1}$ donde las víctimas también hicieron una solicitud en una materia que aún no ha sido enfrentada directamente por este tribunal internacional: el no nacido. ${ }^{2}$ La Corte no aprovechó dicha oportunidad para desarrollar su jurisprudencia en relación con el nasciturus, a pesar de que el tema del no nacido es particularmente interesante en el ámbito del sistema interamericano, cuyo instrumento principal tiene una redacción muy peculiar en materia del derecho a la vida. Éste dispone:

Toda persona tiene derecho a que se respete su vida. Este derecho estará protegido por la ley y, en general, a partir del momento de la concepción. Nadie puede ser privado de la vida arbitrariamente. ${ }^{3}$

El silencio de la Corte en el caso Xákmok motivó la redacción del presente estudio, por lo que conviene describir brevemente dicho asunto. En éste, la comunidad indígena recurrente sostuvo que desde 1990 venía reclamando la propiedad de sus tierras ancestrales en conformidad con la legislación paraguaya, pero sin mayores resultados. ${ }^{4}$ La Comunidad también afirmó que, como consecuencia de la falta de reconocimiento de su derecho a las referidas tierras, sus miembros se vieron forzados a vivir en un lugar que no contaba con los medios necesarios para su subsistencia, por ejemplo, carecía del agua requerida para llevar adelante las

\footnotetext{
${ }^{1}$ Sentencia de Fondo, Reparaciones y Costas de la Corte Interamericana de Derechos Humanos (CtIDH), Comunidad Indígena Xákmok Kásek Vs. Paraguay, 24 de agosto de 2010 (Ser. C) No 214, párr. 2. En adelante: caso Xákmok. Las decisiones de la Corte Interamericana citadas en este artículo se encuentran disponibles en: http://www.corteidh.or.cr/casos.cfm [visitado el 10/08/11].

2 Este artículo utilizará principalmente la expresión "no nacido" o nasciturus, porque ambos términos incluyen tanto a los embriones como a los fetos.

${ }^{3}$ Art. 4.1 de la Convención Americana sobre Derechos Humanos [en adelante Convención Americana, Convención o $\mathrm{CADH}]$.

${ }^{4}$ Caso Xákmok, párr. 2.
} 
necesidades humanas mínimas. Esto los dejó en un estado de precariedad que afectó sus condiciones generales de vida y, en particular, su salud, causando la muerte de decenas de sus integrantes. ${ }^{5}$ Entre los fallecidos la Comunidad nombró a dos no nacidos: (NN) Corrientes Domínguez y (NN) Dermott Ruiz. ${ }^{6}$ La inclusión del reclamo por la muerte de nascituri no fue particularmente audaz, ya que -además de la referencia a la concepción hecha por el artículo 4.1- la Corte se ha referido al no nacido como "bebé", 7 y opiniones separadas de algunos jueces son favorables a una interpretación del derecho a la vida en este sentido. ${ }^{8}$ Además, el Pacto de San José no es el único tratado de derechos humanos que menciona al no nacido, pues el Preámbulo de la Convención sobre los Derechos del Niño, citando la Declaración respectiva, también lo hace. ${ }^{9}$

Al decidir este caso, la Corte afirmó que el Estado quebrantó su obligación de reconocer la propiedad de la Comunidad. Asimismo, después de probar que el Estado estaba en conocimiento de la existencia de un peligro para la vida de los miembros de la Comunidad Indígena, y que no habría hecho uso de las medidas necesarias y razonables para hacer frente a esta situación, lo halló responsable de algunas de las muertes reclamadas por la Comunidad. ${ }^{10}$ Ello, porque la Corte sostuvo que el derecho a la vida no sería sólo fuente de obligaciones negativas -como el no privar arbitrariamente a una persona de su vida-, sino que también de obligaciones positivas dirigidas a proteger y preservar este derecho. ${ }^{11}$

Al decidir sobre la responsabilidad respecto de la muerte de los indígenas, el tribunal distinguió según los casos, hallando al Estado responsable sólo en algunos de ellos. La mayoría de los asuntos fallados en contra del Estado involucraron la falta de una adecuada prevención o respuesta a enfermedades de

\footnotetext{
${ }^{5}$ Ibíd. párrs. 184 \& 223-226.

${ }^{6}$ Ibíd. párr. 228.

7 Sentencia de Fondo, Reparaciones y Costas de la CtIDH, Hermanos Gómez-Paquiyauri Vs. Perú, 8 de julio de 2004 (ser. C) №110, párr. 67.x).

${ }^{8}$ Por ejemplo, el juez Ventura dijo incidentalmente que "[l]a identidad personal tiene su punto de partida en la concepción y su construcción se prolonga durante la vida del ser humano", y el juez Cançado Trindade se refiere a las posibles consecuencias que la violencia ejercida en la mujeres embarazadas puede tener en la mente de los niños "aún antes de su nacimiento". Voto disidente del juez Manuel E. Ventura Robles respecto del punto resolutivo tercero en Sentencia de Fondo, Reparaciones y Costas de la CtIDH, Hermanas Serrano Cruz Vs. El Salvador, 1 de marzo de 2005 (ser. C) № 120, párr. 132 (hay un error en la numeración oficial de este párrafo, ya que en realidad se trata del párr. 14), y el voto razonado del juez Cançado Trindade en Sentencia de Fondo, Reparaciones y Costas de la CtIDH, Penal Miguel Castro Castro Vs. Perú, 25 de noviembre de 2006 (ser. C) № 160, párr. 61, respectivamente.

${ }^{9}$ Convención sobre los Derechos del Niño (1989), párrafo noveno.

${ }^{10}$ Ibíd. párrs. 217 \& 234.

${ }^{11}$ Ibíd. párr. 187.
} 
fácil prevención. ${ }^{12} \mathrm{Al}$ verse enfrentada con el tema del no nacido, el tribunal interamericano afirmó lo siguiente: "la Corte nota que los representantes y la Comisión no han presentado argumentos en relación con la presunta violación del derecho a la vida de 'no natos', por lo que, ante la falta de fundamentación, el Tribunal carece de elementos de juicio para determinar la responsabilidad del Estado respecto a dichos casos". ${ }^{13}$

La precitada afirmación se refiere a la carencia de argumentos jurídicos, no a una falta de certeza en los hechos, pues ya había sido demostrado que los no nacidos estaban muertos, y que la razón de su fallecimiento habrían sido las precarias condiciones de vida de la Comunidad. Este argumento de que la Corte carecía de elementos jurídicos para juzgar sobre un tema de Derecho, contrasta con el uso frecuente que este tribunal hace del principio iura novit curia. Según éste, la Corte no requiere que las partes invoquen o expliquen el Derecho, ya que un tribunal debe conocer, aplicar e interpretar la ley, incluso si las partes no dan mayores explicaciones acerca de sus peticiones. Este alejamiento del principio iura novit curia es especialmente manifiesto en el caso de la Corte Interamericana, pues ésta no sólo usa dicho principio, sino que formula teorías jurídicas propias que expanden su alcance hasta incluir la práctica de la Corte de determinar la violación de derechos que no habían sido reclamados por el peticionario. ${ }^{14}$

Según lo anterior, considerando que la petición de la comunidad Xákmok era clara, que la Convención Americana hace una referencia explícita al momento de la concepción al declarar el derecho a la vida, y que la Corte generalmente aplica el principio iura novit curia, el Tribunal interamericano debiera haber resuelto este asunto. La Corte debiera haber determinado si el nasciturus es o no considerado persona según la Convención, si el Estado era responsable por las dos muertes prenatales referidas en el caso Xákmok, y, consecuencialmente, si estaría obligado al pago de indemnizaciones a los familiares de estas víctimas.

Antes de comenzar el estudio del tema principal de este trabajo, deben recordarse algunas cuestiones básicas del sistema interamericano de derechos humanos. Éste fue creado dentro del contexto de la Organización de los Estados

\footnotetext{
${ }^{12}$ Ibíd. párrs. 231-234. En el párr. 231 la Corte hace hincapié en que muchas de las víctimas eran niños, a cuya protección el Estado se encuentra especialmente obligado. En el párr. 233 la Corte hace una referencia especial al cuidado prenatal, pero dirige su preocupación especialmente hacia la madre embarazada.

${ }^{13}$ Ibíd. párr. 228.

${ }^{14}$ V.gr., Sentencia de Excepción Preliminar, Fondo, Reparaciones y Costas de la CtIDH, Usón Ramírez Vs. Venezuela, 20 de noviembre de 2009 (ser. C) № 207, párr. 53 (se omite la nota al pie). Esta negativa a lidiar con un tema perteneciente al núcleo del derecho a la vida (el no ser privado de ella) es aún más sorprendente si se considera que la Corte se encuentra en una etapa en la que incluso se refiere a derechos obtenidos indirectamente a partir del derecho a la vida, como el derecho a la vida digna (caso Xákmok, párrs. 194 ss.).
} 
Americanos (OEA). ${ }^{15}$ Sus principales instrumentos jurídicos son la Declaración Americana de los Derechos y Deberes del Hombre $(1948)^{16}$ y la Convención Americana sobre Derechos Humanos (1969), también llamado Pacto de San José de Costa Rica. ${ }^{17}$ Este sistema está operado principalmente por dos organismos, la Comisión y la Corte Interamericanas de Derechos Humanos. ${ }^{18}$ La primera está regulada principalmente en la Carta de la OEA, y la segunda en el Pacto de San José. Atendido que los miembros de la OEA no se encuentran obligados a ratificar la Convención, ${ }^{19}$ algunos Estados americanos que se encuentran bajo la jurisdicción de la Comisión no estarán bajo la competencia de la Corte. ${ }^{20}$

Según lo dispuesto en la Carta de la OEA, la Comisión es el organismo encargado de velar por la protección de los derechos reconocidos en la Declaración Americana, y su función principal, es "la de promover la observancia y la defensa de los derechos humanos y de servir como órgano consultivo de la Organización en esta materia". ${ }^{21}$ La Comisión también cuenta con un importante rol según lo establecido en la Convención Americana. Ésta depositó en la -preexistente- Comisión, el rol de antesala cuasi judicial del procedimiento ante la Corte Interamericana. Por su parte, la Corte fue establecida por la Convención como el órgano competente para la protección del amplio catálogo de derechos humanos establecidos en el mismo Pacto de San José.

A continuación, este estudio interpretará el ambiguo artículo 4.1 de la Convención, teniendo en consideración diversos sistemas exegéticos. Asimismo, considerará qué es lo que ha dicho la Comisión Interamericana en esta materia, y evaluará el valor de tales interpretaciones. Este artículo concluirá

\footnotetext{
${ }^{15}$ Para una descripción de este sistema, ver Faúndez Ledesma, Héctor, El Sistema Interamericano de Protección de los Derechos Humanos: Aspectos Institucionales y Procesales. Instituto Interamericano de Derechos Humanos, San José, 2004. En: http://www.iidh.ed.cr/BibliotecaWeb/Varios/Documentos/ BD_125911109/SI_proteccion_ddhh_3e.pdf [visitado el 29/01/11].

${ }^{16}$ Declaración Americana de los Derechos y Deberes del Hombre (1948). En adelante Declaración Americana o Declaración.

${ }^{17}$ Existen también otros instrumentos y tratados de derechos humanos en el sistema de la OEA, por ejemplo, la Convención Interamericana para Prevenir y Sancionar la Tortura (1985), el Protocolo Adicional a la CADH en Materia de Derechos Económicos, Sociales y Culturales (1988), el Protocolo a la CADH Relativo a la Abolición de la Pena de Muerte (1990) y la Convención Interamericana para Prevenir, Sancionar y Erradicar la Violencia contra la Mujer (1994).

${ }^{18}$ En adelante: "Comisión Interamericana" o "Comisión", y "Corte Interamericana", "CtIDH" o "Corte", respectivamente. La primera se halla ubicada en Washington D.C., y la segunda en San José de Costa Rica.

${ }^{19}$ Por ello, once de los treinta y cinco miembros, no son partes de la Convención.

${ }^{20}$ A diferencia de lo que sucede con el Consejo de Europa, donde todos sus miembros deben suscribir el Convenio Europeo para la Protección de los Derechos Humanos y de las Libertades Fundamentales. En adelante: Convención Europea o CEDH.

${ }^{21}$ Carta de la Organización de los Estados Americanos, art. 106.1.
} 
que, si bien una de las posibles interpretaciones de la Convención Americana sostendría que ésta toleraría ciertas legislaciones domésticas que permitan el aborto en circunstancias excepcionales, la Convención Americana declara la personalidad del nasciturus.

\section{INTERPRETACIÓN DEL ARTíCULO 4.1 EN RELACIÓN CON EL NO NACIDO}

En muchas ocasiones la Corte Interamericana se ha referido a las reglas de interpretación referidas en la Convención de Viena sobre el Derecho de los Tratados (CVDT), como una guía en su interpretación del Pacto de San José. 22 La CVDT no sólo fija los criterios según los cuales las normas deben ser interpretadas, sino que también establece un orden de preferencia entre los mismos. Algunas interpretaciones del artículo 4.1 han tenido problemas importantes que han sido el resultado de ignorar los cánones interpretativos codificados en la CVDT. ${ }^{23}$ Por ello, este artículo comenzará siguiendo los principios establecidos en esta fuente de Derecho internacional seguida explícitamente por la Corte Interamericana. Tal fuente exige que los tratados sean interpretados "de buena fe conforme al sentido corriente que haya de atribuirse a los términos del tratado en el contexto de éstos y teniendo en cuenta su objeto y fin" ${ }^{24}$ Además de ello, este trabajo se referirá a la posibilidad de interpretar el Pacto en un sentido evolutivo y pro homine.

\subsection{Principal método de interpretación según la CVDT}

Este estudio no busca juzgar el contenido del artículo 4.1 de la Convención, sino que sólo pretende exponer su contenido y significado. Para hacerlo, interpretará el texto de la Convención, teniendo en consideración su contexto, objeto y fin. ${ }^{25} \mathrm{El}$ primer paso para ello es analizar detalladamente la norma respectiva, que está compuesta por tres oraciones:

$1^{\text {ra: }}$ "Toda persona tiene derecho a que se respete su vida";

\footnotetext{
${ }^{22}$ Este sistema ha sido utilizado desde los primeros años de la Corte (v.gr:: Opinión Consultiva de la CtIDH, Restricciones a la Pena de Muerte (arts. 4.2 y 4.4 Convención Americana sobre Derechos Humanos), 8 de septiembre de 1983 (Ser. A) 3/83, párr. 48), y continúa siéndolo hasta este momento (v.gr. Opinión Consultiva de la CtIDH, artículo 55 de la Convención Americana sobre Derechos Humanos, 29 de septiembre de 2009 (Ser. A) 20/09, párr. 23). Las normas relevantes de la CVDT son los arts. 31-33.

${ }^{23}$ Shelton, Dinah. "Abortion and the Right to Life in the Inter-American System: The Case of 'Baby Boy'", Human Rights Law Journal 2, 1981, p. 313

${ }^{24}$ Art. 31.1 CVDT.

${ }^{25}$ La Corte afirmó originalmente que ella se acogía al "principio de la primacía del texto" (Opinión Consultiva CtIDH 3/83, cit. nota n. 22, párr. 50), pero ahora tiende a hacer hincapié en la importancia de analizar la Convención como un todo (Opinión Consultiva CtIDH 20/09, cit. nota n. 22, párrs. 23 ss.).
} 
$2^{\text {da: }}$ "Este derecho estará protegido por la ley y, en general, a partir del momento de la concepción", y

$3^{\text {ra: }}$ "Nadie puede ser privado de la vida arbitrariamente".

La primera de estas oraciones declara la existencia del derecho a la vida. La segunda se refiere al derecho declarado en la oración anterior, y le impone una obligación al Estado. La tercera puede ser interpretada como estableciendo un nuevo derecho, o explicitando una consecuencia del derecho establecido en la primera oración. Esta última interpretación parece más razonable.

La segunda oración alude a la concepción, lo que obliga al intérprete a dilucidar si dicha norma busca declarar que un organismo humano tiene derechos desde tal momento. ${ }^{26}$ Por ello, será la más importante para el análisis efectuado en este artículo. Dicha oración está interrumpida por la expresión "en general". Sin este elemento intercalado la oración dispondría: Este derecho estará protegido por la ley y a partir del momento de la concepción. ${ }^{27}$ Tal redacción, sin la expresión "en general", fue propuesta por los tres proyectos en los que se basó la Convención Americana. ${ }^{28}$ Atendida la complejidad que presenta la expresión "en general", el estudio de la segunda oración será dividido en dos etapas. En primer lugar, se analizará tal oración sin la expresión "en general", para así entender a qué se le está haciendo la referida salvedad. Después se analizará el sentido de la oración con dicha expresión.

\footnotetext{
${ }^{26}$ Este artículo entiende las palabras concepción y fecundación como sinónimos. La generalidad de la doctrina jurídica no parece embarcarse en la tarea de definir concepción, aunque la mayoría parece identificar estos conceptos con la fertilización, v.gr.: Monroy Cabra, Marco Gerardo, "Derechos y Deberes Consagrados en la Convención Americana sobre Derechos Humanos 'Pacto de San José de Costa Rica'"en La Convención Americana sobre Derechos Humanos, Ed. Secretaría General Organización de los Estados Americanos, Washington D.C., 1980, p. 36; Vivanco Martínez, Ángela. "La Píldora del Día Después", Revista Chilena de Derecho, 35, 2008, p. 544, Gerber, Rudy J. 1970. "Abortion: Two Opposing Legal Philosophies", The American Journal of Jurisprudence, 15, p. 7, y MıLs, Eithne y McConvILL, James, "The 2002 Irish Abortion Referendum: A Question of Constitutionalism and Conscience", European Journal of Law Reform 4, 2002, p. 488. Sin embargo, hay algunas excepciones, como Alston, quien identifica concepción con implantación. ALsTON, Philip. "The Unborn Child and Abortion Under the Draft Convention on the Rights of the Child", Human Rights Quarterly 12, 1990, p. 173.

${ }^{27}$ Esta disposición puede compararse con la segunda oración del artículo 6.1 del Pacto Internacional de Derechos Civiles y Políticos (PIDCP), que establece: "Este derecho estará protegido por la ley".

${ }^{28}$ Ver el Proyecto de Convención sobre Derechos Humanos aprobada por la Cuarta Reunión del Consejo Interamericano de Jurisconsultos, Santiago, Chile, septiembre, 1959; el Proyecto de Convención sobre Derechos Humanos presentado por el Gobierno de Chile a la Segunda Conferencia Interamericana Extraordinaria, Río de Janeiro, 1965, doc. 35, y el Proyecto de Convención sobre Derechos Humanos presentado por el Gobierno del Uruguay a la Segunda Conferencia Interamericana Extraordinaria, Río de Janeiro, 1965, doc. 49, todos ellos disponibles en General Secretariat of the Organization of American States, Anuario Interamericano de Derechos Humanos 1968 / Inter-American Yearbook on Human Rights 1968. Secretariat of the Inter-American Commission on Human Rights, Washington D.C., 1973, pp. 236, $280 \& 298$, respectivamente.
} 


\subsubsection{Interpretación Textual del artículo 4.1}

El sujeto de la oración "este derecho" estará protegido por la ley y a partir del momento de la concepción es "este derecho". La palabra "este" remite al lector al derecho referido en la primera oración, es decir, al derecho al respeto de la vida. Atendido que esta oración está construida en una voz pasiva, ${ }^{29}$ hay una acción que es ejercida sobre el sujeto "este derecho": la "protección". Esta segunda oración no expande ni restringe el derecho a la vida, sino que sólo establece una obligación de protección. En efecto, puede afirmarse que el derecho al respeto de la vida existiría aunque no estuviera protegido por el Estado. ${ }^{30}$ Las expresiones "por la ley" y "a partir del momento de la concepción" están calificando la acción de protección, buscando que el amparo otorgado al derecho a la vida tenga, al menos, tales características. Así, el Estado no puede proteger la vida de cualquier modo, ${ }^{31}$ pues está obligado a protegerla por ley. Del mismo modo, el legislador no puede elegir un momento específico de desarrollo humano para empezar a otorgar esta protección, ${ }^{32}$ pues está obligado a hacerlo desde el momento de la concepción (al menos, como regla general, según se verá más adelante).

El mandato de proteger la vida desde la concepción se basa en el entendido de que el derecho a la vida ya existía en ese momento, pues de otro modo no habría nada que proteger en dicho instante..$^{33}$ Además, debe recordarse que la segunda oración del artículo 4.1 obtiene de la primera oración la idea del derecho a la vida del nasciturus, y esta primera oración declara que toda persona tiene derecho a que se respete su vida. Esto revela que la Convención no sólo declara que el niño no nacido tiene el derecho a la vida, sino que también reconoce su

\footnotetext{
${ }^{29}$ Una redacción en voz activa sería: "La ley protegerá este derecho a partir del momento de la concepción".

${ }^{30}$ A menos que el concepto "derecho" implique alguna forma de protección no legal.

${ }^{31}$ Por ejemplo, no puede decidir protegerla sólo a través de la vía administrativa.

${ }^{32}$ V.gr., veintiocho días después del parto, como en la opinión de Kuhse y Singer. KUHSE, Helga y SINGER, Peter, Should the Baby Live? The Problem of Handicapped Infants. Gregg Revivals, Aldershot, 1985. Estos autores sostienen que no creen que los niños recién nacidos tengan un derecho inherente a la vida (Ibíd. p. 192), y postulan que los Estados debieran autorizar el homicidio de niños discapacitados no deseados hasta el vigesimoctavo día después del parto (Ibíd. pp. 189-197). Kuhse y Singer citan otros autores que también postularían el establecimiento de un período previo a la plena aceptación del niño (Ibíd. p. 195).

${ }^{33}$ Alguien podría sostener que, a contrario sensu, esto daría libertad a los Estados para determinar el momento hasta el cual proteger el derecho a la vida por ley (v.gr. mientras la persona mantenga sus capacidades mentales), pero esta interpretación no estaría de acuerdo con el espíritu de la Convención. La referencia al nasciturus sólo busca protegerlo más efectivamente. Al hacerlo, la Convención sigue la costumbre de otros tratados internacionales de derechos humanos, que se refieren explícitamente a ciertos grupos de personas cuyos derechos han sido repetidamente violados en el pasado, o cuando existe una amenaza de que sus derechos sean violados en el futuro.
} 
calidad de persona. En otras palabras, la primera oración del artículo 4.1 se refiere al derecho de toda persona a que se respete su vida, y la segunda a la obligación de proteger este derecho, en general, a partir del momento de la concepción. La restricción del concepto "persona" a un momento posterior a la concepción -ya sea antes o después de su nacimiento- sería contrario al lenguaje usado por el artículo 4.1.

Las afirmaciones anteriores encuentran también apoyo en otras normas del Pacto de San José, el que exhibe una tendencia general en el sentido ya analizado. Por ejemplo, el artículo 1.2 establece que "[p]ara los efectos de esta Convención, persona es todo ser humano". Esta norma, que no tiene un equivalente en la Convención Europea de Derechos Humanos [CEDH] ni en el Pacto Internacional de Derechos Civiles y Políticos [PIDCP], refuerza la personalidad del no nacido, ya que no es fácil sostener que el nascituri no pertenezca a la especie humana. ${ }^{34}$ Otra norma es la establecida en el artículo 4.5, que prohíbe la aplicación de la pena capital a mujeres embarazadas, pues esa regla no fue establecida en beneficio de la madre (cuyos derechos más básicos son llevados a término al aplicársele tal pena) sino que en favor del niño en desarrollo. ${ }^{35}$ Por lo demás, la Convención Americana no es el único tratado de derechos humanos que hace una declaración expresa referida al no nacido, ya que el noveno párrafo del Preámbulo de la Convención sobre los Derechos del Niño también lo hace. En efecto, éste declara-citando la Declaración de los Derechos del Niño- que "el niño, por su falta de madurez física y mental, necesita protección y cuidado especiales, incluso la debida protección legal, tanto antes como después del nacimiento". ${ }^{36}$

\footnotetext{
${ }^{34}$ Esta regla no busca aclarar la inclusión de la mujer entre los individuos protegidos por el tratado, ya que la Convención no usa la palabra hombre para referirse a las personas, por lo que no existe posibilidad malos entendidos en tal sentido. Uno de los autores que discute que un nasciturus tenga la calidad de ser humano es Philip Alston. Él afirma que en Derecho Internacional no hay precedentes para interpretar que el feto esté incluido en términos como "niño" [child], "ser humano" o "persona humana". Sin embargo, Alston considera que el artículo $4^{\circ}$ de la Convención Americana buscó explícitamente considerar al no nacido como ser humano. ALSTON, "The Unborn Child", cit. nota n. 26, p. 170, nota 68. Por el contrario, Rita Joseph considera que en Derecho internacional considera claramente al nasciturus como ser humano. Ver JosepH, Rita, Human Rights and the Unborn Child. Martinus Nijhoff Publishers, Leiden, 2009.

${ }^{35}$ Ésta es similar a la establecida en el artículo 6.5 del PIDCP. En los travaux préparatoires de tal tratado se afirmó que: "[L]a razón principal para establecer [...] que la sentencia de muerte no debiera aplicarse a una mujer embarazada fue para salvar la vida de un niño nonato inocente", A/3764 párr. 118, reimpreso en RamCharan, B. G. (Ed.), The Right to Life in International Law. Martinus Nijhoff Publishers, Dordrecht, 1985, p. 53. Traducido libremente por el autor.

${ }^{36}$ Es importante notar que en algunas ediciones del Oxford English Dictionary, la primera acepción de la palabra "child" incluye al no nacido. Ver Shorter Oxford Eglish Dictionary, 6a ed., Vol. I, 2007, p. 397, o también The Compact Edition of the Oxford English Dictionary, Vol. I, 1971, p. 396. Hay dos interpretaciones sobre si la Convención sobre los Derechos del Niño es aplicable o no al nasciturus.
} 
Se ha sugerido que la incapacidad del no nacido de gozar de todos los derechos establecidos en la Convención es una muestra de su falta de personalidad. ${ }^{37}$ Sin embargo, existen derechos en el Pacto de San José que no pueden siquiera ser ejercitados por adultos, especialmente cuando ellos se encuentran en situaciones fuera de lo común, como sucede con personas en estado vegetal. Asimismo, hay muchos derechos que no pueden ser ejercidos plenamente por niños ya nacidos, especialmente durante sus primeros años. Además, varios derechos fueron establecidos sólo para algunas categorías de personas, como sucede con los derechos de los ciudadanos y de los menores. Por tanto, la imposibilidad de que una persona ejercite ciertos derechos declarados en un tratado de derechos humanos no le impide ejercitar los derechos restantes, ni le hace perder su calidad de persona.

El razonamiento previo aún no ha incluido un análisis de la frase "en general", la que requiere ser interpretada. Su sentido literal es simplemente que la protección del derecho a la vida desde el momento de la concepción admite ciertas excepciones. En otras palabras, el Pacto de San José entiende que habrá situaciones que pueden oponer obstáculos a la protección del derecho a la vida desde el momento de la concepción. Sin embargo, aunque estos óbices pueden impedir la protección del nasciturus, no lo hacen perder su calidad de persona. Esto sucede porque la expresión "en general" fue intercalada en la oración relacionada con la protección del derecho a la vida, no en la que reconoce el derecho mismo. ${ }^{38}$ La extensión de la frase "en general" no fue definida en la Convención, por lo que será analizada más adelante.

Philip Alston considera que no. Alston, "The Unborn Child", cit. nota n. 26, pp. 177 \& 178. Bruce Abramson considera que sí. Abramson, Bruce, Violence Against Babies: Protection of Pre- and PostNatal Children Under the Framework of the Convention on the Rights of the Child. Versión Revisada. World Family Policy Center, Utah, 2006, pp. 56-103 \& 195-211.

37 Medina Quiroga, Cecilia, La Convención Americana: Vida, Integridad Personal, Libertad Personal, Debido Proceso y Recurso Judicial. Universidad de Chile, Facultad de Derecho, Centro de Derechos Humanos, 2003, p. 75.

${ }^{38}$ Hay unos pocos autores que consideran que es la vida, no la protección, la que puede estar sujeta a excepciones en su comienzo a partir del momento de la concepción. Esta posición, junto con olvidar que la expresión "en general" se intercaló en la segunda oración (referida a la protección), no considera que los procesos biológicos -un ejemplo de los cuales es el comienzo de la vida-son comunes a todos los seres humanos. Por tanto, aunque diversos sistemas legales puedan considerar que sendos momentos constituyen el comienzo de la vida para efectos jurídicos, tales instantes debieran ser los mismos para todos aquellos que se encuentran sujetos a una misma jurisdicción. Entre los referidos autores se encuentran Pasqualucci y Cançado Trindade. Pasqualuccl, Jo. M., The Practice and Procedure of the Inter-American Court of Human Rights. Cambridge University Press, Cambridge, 2003, p. 341 y TANNER, Lauri R. "Interview with Judge Antônio A. Cançado Trindade, Inter-American Court of Human Rights", Annual Survey of International and Comparative Law XVI, 2010, p. 177. El juez Cançado Trindade ha señalado que una de las razones por las que algunos Estados no han ratificado la Convención son sus legislaciones favorables al aborto. Ibíd. 


\subsubsection{Otras Consideraciones para una Interpretación Textual}

La CVDT requiere que las interpretaciones textuales estén de acuerdo con el contexto, objeto y fin de un tratado. Atendido que, para la interpretación de la personalidad del no nacido no existen acuerdos o instrumentos, prácticas o reglas, de aquellos descritos en la CVDT como formando parte del contexto de un tratado, ${ }^{39}$ esta sección tratará especialmente con el objeto y propósito del Pacto de San José. La Corte Interamericana ha sostenido que el objeto de la Convención es "la protección de los derechos fundamentales de los seres humanos, independientemente de su nacionalidad, tanto frente a su propio Estado como frente a los otros Estados contratantes". ${ }^{40}$ Este objeto y fin se cumpliría con la interpretación previamente descrita del artículo 4.1, pues es entendible que una Convención sobre garantías básicas busque proteger la vida humana como tal, con independencia de su nivel de desarrollo.

Alguno podría argumentar que la interpretación referida -que podría restringir los abortos en forma importante, dependiendo de la lectura que se haga de la expresión "en general"- estaría en oposición a la protección de otros derechos que suelen considerarse como relacionados con el aborto, como el derecho a la privacidad y a la integridad física de la madre. Parte de este asunto será abordado al momento de analizar la posibilidad de leer la Convención en una forma evolutiva. Sin embargo, debe tenerse presente que la extensión de estos otros derechos varía según lo que disponga el instrumento en el cual se hallan declarados. Así, a pesar de que los derechos a la privacidad y a la integridad física han sido considerados en otras jurisdicciones como relacionados con la realización de abortos, esto

\footnotetext{
${ }^{39}$ Arts. 31.2 y 31.3 de la CVDT. En efecto, no existen otros acuerdos o instrumentos concertados o aceptados por todas las partes con motivo de la celebración del tratado, ni acuerdos entre las partes acerca de la interpretación o aplicación de esta disposición en particular, ni otras reglas relevantes de Derecho internacional aplicables en esta materia (Cfr., arts. 31.2 y 31.3). El Protocolo Adicional a la CADH en Materia de Derecho Económicos, Sociales y Culturales (1988) y la Convención Interamericana para Prevenir, Sancionar y Erradicar la Violencia contra la Mujer (1994) contienen algunas reglas sobre la protección de la familia y de la mujer, pero no se refieren al tema del no nacido, no apuntan estrictamente a interpretar el Pacto de San José, y no establecen reglas internacionales en materia del derecho a la vida. Por ello, no pueden ser utilizadas propiamente como contexto para analizar si el no nacido debe ser considerado una persona según la Convención Americana.

${ }^{40}$ Opinión Consultiva de la CtIDH, Restricciones a la Pena de Muerte (arts. 4.2 y 4.4 Convención Americana sobre Derechos Humanos), 8 de septiembre de 1983 (Ser. A) 3/83, párr. 65. En fechas más recientes, la Corte parece haber ampliado el referido objeto, al no hacer calificaciones sobre el sujeto frente a quién se realiza la protección. En efecto, en el caso Boyce la Corte define su objeto, simplemente, como "la protección de los derechos fundamentales de los seres humanos". Sentencia de Excepción Preliminar, Fondo Reparaciones y Costas de la CtIDH, Boyce y otros Vs. Barbados, 20 de noviembre de 2007, (Ser. C) N 169, párr. 15. Pareciera ser más acertado afirmar que la finalidad de la Convención es la creación de estándares regionales vinculantes para la protección de los derechos humanos y el establecimiento de un sistema para supervisar su cumplimiento.
} 
puede no ser así en la Convención Americana. En este sentido, el texto del Pacto de San José - sin perjuicio de la expresión "en general" - no tiene ninguna norma relacionada con el tema del aborto, lo que contrasta con la declaración explícita que hace este tratado en materia de la personalidad del no nacido. Aún más, la expresión "en general" podría ser interpretada como un reflejo de la posición de la Convención en un posible conflicto entre los derechos a la vida y otros, como el derecho a la privacidad y a la integridad física. Ello, porque dicha expresión implica que la Convención admitiría ciertas interferencias con el derecho a la vida, pero que ellas pueden ocurrir sólo en forma excepcional.

El enfoque de la Convención frente al derecho a la vida podría ser considerado como un valor guía de este sistema regional, pues refleja la especial importancia que las legislaciones nacionales conceden al no nacido en América. En efecto, varias Constituciones políticas -algunas promulgadas recientemente, en los años 2008 y 2010 - protegen la vida desde el momento de la concepción. ${ }^{41}$ Asimismo, esta preocupación también puede observarse en la legislación de varios países cuyas Constituciones no hacen referencia explícita al momento de la concepción, pero que prohíben toda forma de aborto directo, como sucede en el caso de Chile, Nicaragua y Honduras. ${ }^{42}$ Las legislaciones de El Salvador y la República Dominicana, cuyas constituciones protegen la vida desde la concepción, también prohíben toda forma de aborto directo. ${ }^{43}$ Otro caso interesante es

${ }^{41}$ Constitución de la República del Ecuador (2008), art. 45; Constitución Política de la República Dominicana (2010), art. 37 (esta disposición no existía en Constituciones previas de este Estado); Constitución de El Salvador (1992), art. 1(2); Constitución Política de la República de Guatemala (1985), art. $3^{\circ}$ (todas las referidas constituciones protegen la vida desde el momento de la concepción, sin excepciones análogas a la frase "en general"); Constitución Nacional de la República del Paraguay (1992), art. $4^{\circ}$ (tiene la misma redacción que la CADH, incluyendo la frase "en general"), y la Constitución Política del Perú (1993), art. $2^{\circ} N^{\circ} 1$ (establece: "El concebido es sujeto de derecho en todo cuanto le favorece"). Además de estas constituciones de Estados miembros, muchas constituciones de estados federados también reconocen la existencia de la vida desde el momento de la concepción, haciendo o no mención explícita a ciertas excepciones. Por ejemplo, la mayoría de los estados federados de México han aprobado modificaciones constitucionales que reconocerían la vida desde el momento de la concepción, v.gr.: Chihuahua, Sonora, Baja California, Morelos, Colima, Puebla, Jalisco, Durango, Nayarit, Guanajuato (la mayoría de estas modificaciones fueron aprobadas durante los años 2008 y 2009, como reacción a la liberalización del aborto en Ciudad de México). Este es también el caso de varias constituciones de provincias argentinas, como las de Córdoba, Tucumán, Tierra del Fuego y Salta. También en el caso de Argentina, al momento de ratificar la Convención sobre los Derechos del Niño, dicho Estado hizo una declaración que señala: "se entiende por niño todo ser humano desde el momento de su concepción y hasta los 18 años de edad".

${ }^{42}$ Ver: Código Penal (Chile) arts. 342-345, Código Penal (Nicaragua) arts. 143-145, y Código Penal (Honduras) Arts. 126-129. Todos estos países solían contar con excepciones a la prohibición del aborto directo. Generalmente Honduras no es contada entre los países que prohíben el aborto en toda situación, pero su legislación penaliza toda forma de aborto.

${ }^{43}$ Código Penal (El Salvador) arts. 133-137, y Código Penal (República Dominicana) art. 317. La legislación salvadoreña solía contemplar excepciones a la prohibición del aborto directo. Sin perjuicio de lo dispuesto en su legislación Penal, la República Dominicana deja impunes ciertos abortos, ver nota 171. 
el de Costa Rica, cuya jurisprudencia constitucional prohíbe la fecundación in vitro en su estado actual de desarrollo, pues su Corte Suprema afirmó que esta técnica conlleva altas tasas de mortalidad embrionaria. ${ }^{44}$ Incluso más, podría no ser coincidencia que, mientras todos los Estados recién nombrados son partes de la Convención, la mayoría de los Estados con leyes liberales de aborto no lo son (v. gr. Canadá, EE.UU., Guyana y Cuba). ${ }^{45}$

La doctrina está consciente de que el artículo 4.1 de la Convención protege al no nacido, aunque este entendimiento ha tenido ciertas excepciones. ${ }^{46}$ Así, en los primeros años de la Convención, Marco Monroy Cabra, quien Ilegaría después a ser Presidente de la Comisión Interamericana de Derechos Humanos, escribió: "Salta a la vista que el Pacto de San José es más avanzado [que el PIDCP] ya que protege la vida 'desde el momento de la concepción', lo cual puede crear dificultades para los Estados que permiten el aborto en ciertas circunstancias". ${ }^{47}$ Monroy llega a sostener que "[e]l derecho a nacer es una manifestación particular del derecho a la vida, por lo cual la gran mayoría de Estados tipifican como delito el aborto".$^{48}$

En nuestros días, muchos juristas dedicados a los derechos humanos entienden que la Convención protege la vida del nasciturus. Ejemplo de ellos son Cançado Trindade ${ }^{49}$ Rodríguez Rescia, ${ }^{50}$ Joseph, ${ }^{51}$ Pasqualucci, ${ }^{52}$ etc. ${ }^{53}$ Además de estos

\footnotetext{
${ }^{44}$ Sentencia de la Corte Suprema de Costa Rica, Sala Constitucional, 15 de marzo de 2000, Sentencia: 02306, Expediente: 95-001734-0007-CO, "Considerando" IX. En: http://200.91.68.20/scij/busqueda/ jurisprudencia/jur_repartidor.asp?param $1=$ XYZ\&param2 $=1 \&$ nValor $1=1 \& n$ Valor2 $=128218 \&$ strTipM $=$ T\&IResultado=10 [visitado el 17/07/11]. Sin embargo, esta decisión permitiría en el futuro la aplicación de esta técnica, con tal de que se reduzca la mortalidad embrionaria. Este artículo se referirá más adelante a un caso presentado a la Corte sobre este tema.

${ }^{45}$ Este último tampoco es un miembro activo de la OEA.

${ }^{46}$ V.gr. Cecilia Medina afirma que la Convención es compatible con, o incluso requiere, legislaciones liberales en materia de aborto (Medina, La Convención, cit. nota n. 37, 66 ss.). Scott Davidson tiene un enfoque menos radical, y afirma que ni la Declaración ni la Convención responden las cuestiones de si un feto es un ser humano, o de cuándo éste cesa de existir (DAvidson, Scott, "The Civil and Political Rights Protected in the Inter-American Human Rights System", en The Inter-American System of Human Rights, O.U.P., Oxford, 1998, p. 216).

${ }^{47}$ Monror, "Derechos", cit. nota n. 26, p. 36.

${ }^{48}$ Ibíd.

49 En TANner, "Interview", cit. nota n. 38, p. 177.

${ }^{50}$ Rodríguez Rescia, Víctor, Las Sentencias de la Corte Interamericana de Derechos Humanos: Guía Modelo para su Lectura y Análisis Instituto Interamericano de Derechos Humanos, San José, 2009, p. 11.

${ }^{51}$ JOSEPH, Human Rights, cit. nota n. 34, pp. 213 ss.

52 Pasqualuccl, "The Practice", cit. nota n. 38, p. 341.

${ }^{53}$ Otros ejemplos de estos autores son: Patricia Palacios (Palacios Zuloaga, Patricia, "La Aplicabilidad del Derecho a la Vida al Embrión o Feto en la Jurisprudencia Internacional" Anuario de Derechos Humanos
} 
autores, algunas autoridades gubernamentales también han adoptado esta interpretación. Por ejemplo, el año 2008 el -entonces- presidente uruguayo Tabaré Vázquez Rosas invocó el articulo 4.1 de la Convención al vetar un proyecto de ley que buscaba introducir el aborto hasta la duodécima semana de embarazo. ${ }^{54}$ Asimismo, el Standing Senate Committee on Human Rights de Canadá mostró su preocupación por la amenaza que el artículo 4.1 generaba para la preservación del status quo canadiense en materia de aborto. ${ }^{55}$

1, 2005, p. 79); José Alfredo de Oliveira Baracho (De Oliveira Baracho, José Alfredo, "A Prática Jurídica no Domínio da Proteção Internacional dos Direitos do Homem (A Convenção Européia dos Direitos do Homem)" en Corte Interamericana de Derechos Humanos. Liber Amicorum Héctor Fix-Zamudio. Vol I, Ed. Secretaría de la Corte Interamericana de Derechos Humanos, 1998, p. 398); Héctor Gros (Gros Espiell, Héctor, La Convención Americana y La Convención Europea de Derechos: Análisis Comparativo. Editorial Jurídica de Chile, Santiago, 1991, pp. 82 \& 83); Nihal Jayawickrama (Jayawickrama, Nihal, The Judicial Application of Human Rights Law. Cambridge University Press, Cambridge, 2002, p. 248), y Rodolfo Barra (BARRA, Rodolfo Carlos, La Protección Constitucional del Derecho a la Vida. Albeledo Perrot, Buenos Aires, 1996, p. 60, citado en Corral TalCiani, Hernán, Derecho Civil y Persona Humana: Cuestiones Debatidas, LexisNexis, Santiago, 2007, p. 86). Entre aquellos que adoptan esta posición también hay autores que consideran que la Convención es compatible con una aproximación liberal al tema del aborto. Este es el caso del canadiense William Schabas, quien considera que el artículo 4.1 no impone, en general, la obligación de prohibir el aborto, aunque podría requerir que los Estados regulen su práctica y lo prohíban en ciertos casos, como podría ser después de un cierto número de semanas de embarazo. SChabAs, William A., "Canadian Ratification of the American Convention on Human Rights". Netherlands Quarterly of Human Rights, 16, 1998, p. 328.

${ }^{54}$ Presidencia de la República Oriental del Uruguay, Comunicación Dirigida al Señor Presidente de la Asamblea General, 14 de noviembre de 2008. En: http://www.presidencia.gub.uy/_Web/proyectos/2008/11/ s511_00001.PDF [visitado el 29/01/11]. La afiliación política de izquierdas del Presidente Vázquez es una expresión de que en América Latina las posiciones respecto al aborto no pueden ser presentadas en forma simplista como un debate entre derecha e izquierda. Otro ejemplo de ello es que la nueva ley nicaragüense en contra del aborto fue apoyada por el Frente Sandinista de Liberación Nacional (FSLN); que la nueva Constitución ecuatoriana, que protege al no nacido, fue discutida y promulgada durante el gobierno de Rafael Correa, y que las reformas constitucionales protegiendo la vida desde la concepción en los estados mexicanos fueron, en muchos casos, apoyados por miembros del Partido Revolucionario Institucional (PRI). Asimismo, el hecho de que el presidente Tabaré Vázquez sea un agnóstico (LisCANO, Carlos, Conversaciones con Tabaré Vázquez. Colihue, Buenos Aires, 2004, pp. 33 \& 34), y que Nicaragua esté entre los países hispanos de América con la menor proporción de católicos $(58 \%$, con un $16 \%$ que declara no tener religión) (Gobierno de Nicaragua. Instituto Nacional de Estadísticas y Censo, VIII Censo de Población y IV de Vivienda, 2005: Población: Características Generales. Gobierno de Nicaragua, S.D., 2006, p. 195), muestran que en Latinoamérica las posiciones en materia de aborto tampoco pueden ser explicadas únicamente diciendo que se deben a la posición de la Iglesia católica. Esto también es entendido en el estudio de Mala Htun, quien sostiene que la intensidad de las creencias religiosas no corresponde con el curso de las reformas en materia género y reproducción en América Latina. HTUN, Mala, Sex and the State: Abortion, Divorce, and the Family Under Latin American Dictatorships and Democracies. Cambridge University Press, Cambridge, 2003, p. 27.

${ }^{55}$ The Senate, Standing Senate Committee on Human Rights, Enhancing Canada's Role in the OAS: Canadian Adherence to the American Convention on Human Rights. S.D., 2003, p. 61. En: http://www.parl.gc.ca/37/2/ parlbus/commbus/senate/com-e/huma-e/rep-e/rep04may03-e.pdf [visitado el 29/01/11]. 
Si el intérprete considerara que la Convención no buscó declarar y proteger el derecho a la vida desde el momento de la fecundación, la referencia que el Pacto hace a la concepción acabaría siendo inútil. Ello iría en contra del principio interpretativo básico de que las disposiciones de una norma deben ser entendidas de un modo en que tengan efecto - ut res magis valeat quam pereat-. Por ello, debe deducirse que el texto de la Convención, analizado a la luz de su contexto, objeto y fin, considera que el no nacido es titular del derecho a la vida, a pesar de que pueda haber ciertas excepciones a su protección, cuya extensión será analizada más adelante en este trabajo. La siguiente sección se dedicará, a pesar del principio de in claris not fit interpretatio, a considerar otros procedimientos interpretativos, como el recurso a los trabajos preparatorios del Pacto de San José.

\subsection{Método de interpretación complementario: Trabajos preparatorios}

Los trabajos preparatorios son sólo un método complementario de interpretación según la CVDT. ${ }^{56}$ Ellos deben ser usados, ya sea para confirmar el sentido de un tratado, o como auxilio para interpretar aquellos cuyo texto es ambiguo u obscuro, o pueda llevar a un resultado que es manifiestamente absurdo o irracional. ${ }^{57} \mathrm{~A}$ pesar de ello, varias de las elucidaciones del artículo 4.1 se han basado principalmente en los trabajos preparatorios. ${ }^{58}$ Sin embargo, incluso este método complementario de interpretación apoya la idea de que el recién concebido es considerado una persona en el sistema interamericano.

Según se afirmó previamente, los tres proyectos originales de la Convención proponían la aprobación de una oración que dispusiera: "Este derecho estará protegido por la ley a partir del momento de la concepción". ${ }^{59}$ Sin embargo, al recibir estos proyectos y hacer su propuesta, la Comisión "trató de suavizar el rigor del principio consagrado en el Proyecto y por esto propuso intercalar las palabras 'en general'", ${ }^{60}$ pero consideró que "por razones de principio era fundamental" mantener en esta disposición la referencia a la concepción. ${ }^{61}$ Esta redacción no siguió la recomendación del relator, quien sugirió "dejar abierta la cuestión" de

\footnotetext{
56 Art. 32.

57 Fitzmaurice, Malgosia, "The Practical Working of the Law of Treaties", International Law. 2a ed., O.U.P., Oxford, 2006, p. 201.

${ }^{58}$ Cfr. Shelton, "Abortion", cit. nota n. 23, p. 314.

${ }^{59}$ Ver nota 33.

${ }^{60}$ Estudio Comparativo entre los Pactos de las Naciones Unidas sobre Derechos Civiles, Políticos, Económicos, Sociales y Culturales y los Proyectos de Convención Interamericana sobre Derechos Humanos, en General SeCretariat, Anuario Interamericano, cit. nota n. 28, p. 192.

${ }^{61}$ Ibíd. p. 98. El destacado es nuestro.
} 
la protección del derecho a la vida -eliminando la referencia a la concepción-, para así evitar cualquier posibilidad de conflicto con el PIDCP. ${ }^{62}$

Durante la tramitación de la Convención, la norma relevante del Pacto de San José fue entendida como reconociéndole personalidad al no nacido -con todas sus consecuencias-, y fue por ello que Brasil propuso suprimir la frase "y, en general, a partir del momento de la concepción". Este Estado argumentó que, a pesar de que su Código Civil protegía los derechos del no nacido desde el momento de la concepción, su Código Penal permitía la práctica de abortos cuando un embarazo amenazara la vida de la madre, o cuando hubiera sido el resultado de una violación. ${ }^{63}$ Brasil también argumentó que la expresión "en general, a partir del momento de la concepción" era vaga, por lo que no sería efectiva para evitar que los Estados legalizaran el aborto. Por ello, afirmó que esta frase debiera ser eliminada, permitiendo que los Estados dictaran las normas sobre el aborto que estimaran adecuadas. ${ }^{64}$ La propuesta de Brasil fue apoyada por los Estados Unidos. ${ }^{65}$

La propuesta de Brasil fue fuertemente opuesta por Venezuela, que argumentó que las leyes internas no podían ser usadas para decidir sobre derechos civiles y políticos a nivel universal; que la Convención no podía hacer concesiones en relación con la existencia de la vida desde el momento de la concepción, y que sería inaceptable que la Convención no estableciera un principio como éste. ${ }^{66}$ Por su parte, la República Dominicana propuso copiar la disposición del derecho a la vida del PIDCP, la que no hace referencia al momento de la concepción. ${ }^{67}$ Ello habría tenido los mismos efectos prácticos que suprimir la disputada frase. Según

\footnotetext{
${ }^{62}$ Ibíd. p. 192. El relator fue el brasileño Carlos Dunshee de Abranches.

${ }^{63}$ Secretaría General dela Organización de los Estados Americanos, Conferencia Especializada Interamericana sobre Derechos Humanos: Actas y Documentos, OEA/Ser.K/XVI/1.2, San José, Costa Rica, 7-22 de noviembre de 1969. Secretariat of the Inter-American Commission on Human Rights, Washington D.C., 1973, p. 121. En http://www.corteidh.or.cr/tablas/15388.pdf [visitado el 30/01/11]. En el texto de los travaux préparatoires Brasil utilizó la palabra estupro. Sin embargo, el Código Penal de Brasil utiliza la palabra portuguesa estupro como referida a violación. Cfr. Código Penal (Brasil) art. 128 y el título que antecede al art. 213.
}

${ }^{64}$ Secretaría General, cit. nota n. 63, pp. 121 \& 159.

${ }^{65}$ El delegado de EE.UU. fue mucho más influyente en materia de incitación al odio y libertad de expresión, ya que su propuesta de modificación fue aceptada por los miembros de la OEA. Probablemente ello respondió a su advertencia de que lo contrario haría dicha norma incompatible con la garantía constitucional estadounidense de la libertad de expresión (Ibíd. p. 444). En materia de aborto, tal delegado no podría haber esgrimido argumentos basados en la Constitución de EE.UU., ya que el caso Roe Vs. Wade-donde se afirmó que el aborto formaba parte del derecho a la privacidad-fue decidido sólo en 1973 (Sentencia de la Corte Suprema de EE.UU., Roe v. Wade, 410 U.S. 113 (1973)).

${ }^{66}$ Secretaría General, cit. nota n. 63, pp. 159-160.

${ }^{67}$ Ibíd., p. 57. 
la República Dominicana, el motivo por el cual propuso suprimir esta frase fue el fortalecimiento de "conceptos universales de los derechos humanos" ${ }^{68}$ Ecuador era de la opinión contraria, ya que proponía la eliminación de la expresión "en general", protegiendo así la vida desde la concepción en toda circunstancia. ${ }^{69}$

Por último, la redacción actual de la Convención fue aprobada por la mayoría de los Estados americanos. ${ }^{70}$ El resultado del actual artículo 4.1 no es el propuesto por los proyectos originales o por Ecuador, de modo que admite excepciones a la protección del derecho a la vida -las que serán analizadas en la sección final de este trabajo-. Sin embargo, el texto vigente es el mismo que fue defendido por Venezuela como uno en el que "no puede haber concesiones" a la existencia del derecho a la vida desde el momento de la concepción. ${ }^{71}$ Por ello, a pesar de que el artículo 4.1 utilice la expresión "en general", los trabajos preparatorios permiten afirmar que la actual redacción de dicha norma es una solución de principios, no de concesiones entre los países americanos.

\subsection{Interpretaciones evolutiva y pro homine ${ }^{72}$}

De lo que se ha dicho hasta el momento, queda claro que el texto de la Convención considera que el no nacido es persona y titular del derecho a la vida. Sin embargo, no está de más preguntarse si una interpretación evolutiva o pro homine podría haber cambiado esta lectura textual, tornando el derecho a la vida más restrictivo. Este análisis es especialmente relevante, ya que la Corte ha utilizado estos métodos de interpretación en considerables ocasiones. ${ }^{73}$ Este

\footnotetext{
${ }^{68} \mathrm{Ibíd}$. La idea de que República Dominicana no tenía las mismas intenciones que Brasil y los Estados Unidos es apoyada por el hecho de que tal Estado no firmó la declaración interpretativa que estos últimos hicieron al momento de ver rechazada su propuesta. Debe notarse que la actual Constitución de ese país dispone que el "derecho a la vida es inviolable desde la concepción hasta la muerte" (República Dominicana Const. Art. 37 (2010)).

${ }^{69}$ Secretaría General, cit. nota n. 63, p. 160.

${ }^{70}$ Desafortunadamente los trabajos preparatorios no detallan cómo votaron los delegados. Ibíd. p. 160.

${ }^{71}$ Secretaría General, cit. nota n. 63, p. 160.

${ }^{72}$ El principio pro homine es una herramienta hermenéutica utilizada en varias jurisdicciones. Según éste, las normas deben ser interpretadas del modo más favorable al ser humano, con tal de que estas lecturas sean coherentes con las disposiciones que están siendo interpretadas.

${ }^{73}$ La Corte sostiene que las interpretaciones evolutivas son compatibles con las reglas de la CVDT. Cfr. Opinión Consultiva de la CtIDH, El Derecho a la Información sobre la Asistencia Consular en el Marco de las Garantías del Debido Proceso Legal, 1 de octubre de 1999 (Ser. A) 16/99, párrs. 114 \& 115, y Opinión Consultiva de la CtIDH, Interpretación de la Declaración Americana de los Derechos y Deberes del Hombre en el Marco del artículo 64 de la Convención Americana sobre Derechos Humanos, 14 de julio de 1989 (Ser. A) 10/89, párr. 37. Antes de interpretar un tratado en forma evolutiva, es necesario determinar si fue redactado como un instrumento susceptible de ser interpretado de tal modo. Al hacerlo, debe examinarse la intención de las partes y el texto del tratado. ARATo, Julian, "Sub-
} 
artículo no tomará una posición en el debatido asunto de si las interpretaciones evolutivas son o no adecuadas. No obstante ello, se referirá a las principales características de este sistema de interpretación, para determinar así si es aplicable al momento de interpretar el artículo 4.1.74

El concepto mismo de interpretación evolutiva se encuentra actualmente en desarrollo, por lo que sus contornos aún no son claros. ${ }^{75}$ Sin embargo, parece haber consenso en la práctica internacional de que un tratado puede evolucionar si es que utiliza "conceptos evolutivos"-es decir, términos abiertos- ${ }^{76}$ al determinar el contenido de un derecho en particular. ${ }^{77}$ Tal método de interpretación puede ser usado para extender el contenido de un derecho de un modo en que no fue previsto por quienes redactaron el tratado, o para apartarse de precedentes previos. Sin embargo, una interpretación evolutiva no puede derivar de un tratado internacional un derecho que no se encontraba incluido en éste desde su creación, especialmente cuando el silencio sobre tal derecho fue deliberado. ${ }^{78}$ A fortiori, las interpretaciones evolutivas no deben contrariar las disposiciones textuales de una convención. En efecto, lo único que puede ser

sequent Practice and Evolutive Interpretation: Techniques of Treaty Interpretation over Time and Their Diverse Consequences". The Law and Practice of International Courts and Tribunals, 9, 2010, p. 444. Sin embargo, atendido que la Corte ya ha afirmado que el Pacto de San José permite interpretaciones evolutivas, este estudio no ahondará en dicho punto.

${ }^{74}$ No existe consenso en la doctrina acerca de la adecuación de las interpretaciones evolutivas. Para una opinión que justifica enfoques originalistas sobre la base de que el Derecho internacional es creado mediante acuerdos en puntos específicos, ver OrakHELASHVILI, Alexander, The Interpretation of Acts and Rules in Public International Law. O.U.P., Oxford, 2008.

${ }^{75}$ Arato, "Subsequent", cit. nota n. 73, p. 444, nota 5, refiriéndose a un argumento de Malgosia Fitzmaurice.

${ }^{76} \mathrm{lbíd}$. p. 468. Arato también se refiere a un fundamento para la evolución de los tratados aún más discutido, el que se basa en el objeto y el propósito de un tratado. Él considera que una evolución basada en esta fundamentación podría ser usada sólo cuando ello es necesario para darle efecto al objeto y propósito. Arato afirma que la "mera conveniencia" para aplicar una interpretación evolutiva sería una fundamentación insuficiente, ya que ello podría llevar no sólo a una "aplicación superflua de la interpretación evolutiva", sino que también a "socavar seriamente la certeza en el Derecho de los tratados, ya que cualquier cosa podría considerarse como evolutiva". Ibíd. en 476 (las frases citadas han sido libremente traducidas por el autor). Sin embargo, incluso la evolución basada en el objeto y propósito del tratado no puede contrariar las disposiciones textuales de un tratado.

${ }^{77}$ La utilización de estos conceptos puede deberse a que durante la discusión del tratado fue imposible llegar a una definición más precisa. Cfr. Aıston, Philip, "The Historical Origins of the Concept of 'General Comments' in Human Rights Law' en The International Legal System in Quest of Equity and Universality / L'Ordre Juridique International, un Système en Quête D'Équité et D'Universalité: Liber Amicorum Georges Abi-Saab, Kluwer Law International, 2001, p. 776.

${ }^{78}$ Sentencia del Tr. Eur. D.H., Johnston and Others v. Ireland, 1986, 112 (Ser. A) párr. 53. Las decisiones del Tribunal Europeo de Derechos Humanos pueden encontrarse en: http://cmiskp.echr.coe.int/tkp197/ search.asp?skin=hudoc-en [visitado el 30/01/11]. 
interpretado en forma evolutiva -y, por tanto, ser expandido a ámbitos de aplicación imprevistos- es una materia que ya ha sido implícita o explícitamente incluida en el texto de un tratado. ${ }^{79}$ Por ello, la declaración expresa que hace la Convención sobre el derecho a la vida del no nacido no puede ser interpretada en un modo que prive al embrión o feto de su personalidad.

A pesar de que el argumento previamente descrito es concluyente, debe notarse que las interpretaciones evolutivas o progresivas de los tratados de derechos humanos son usadas para extender el alcance de los derechos establecidos en instrumentos internacionales, no para reducirlos. Por ejemplo, una interpretación evolutiva de la Convención podría permitir que la Corte amplíe el listado de garantías procesales que beneficien a una persona que se encuentre bajo arresto, v.gr. incluyendo "los derechos a no autoincriminarse y a declarar en presencia de abogado", pero no para disminuirlos. ${ }^{80}$ Las regresiones no son aceptadas por quienes favorecen las interpretaciones progresivas. ${ }^{81}$ Esto es especialmente así cuando uno se enfrenta con el derecho a la vida, ya que, "[e]n razón del carácter fundamental del derecho a la vida, no son admisibles enfoques restrictivos del mismo" ${ }^{82}$ Por ello, podría afirmarse que interpretaciones progresivas sólo podrían hacer el derecho al respeto a la vida más exigente. ${ }^{83}$

Sin perjuicio de lo anterior, teniendo en consideración lo que ha sido hecho en otros sistemas internos e internacionales, podría argumentarse que interpretar la Convención como compatible con legislaciones que permitan el aborto no es restringir el derecho a la vida, sino que potenciar otros derechos, como el de la privacidad o el de la integridad personal. ${ }^{84}$ En efecto, algunas jurisdicciones domésticas y cortes internacionales han afirmado que el aborto está incluido dentro del área exenta de intervención estatal creada por el derecho a la privacidad. ${ }^{85}$ Sin embargo, esto ha sucedido en Estados en los que el estatus constitucional del no nacido no se encuentra establecido en forma tan clara como en la Convención, la que explícitamente reconoce la personalidad desde

\footnotetext{
${ }^{79}$ Mahoney, Paul, "Judicial Activism and Judicial Self-Restraint in the European Court of Human Rights: Two Sides of the Same Coin" Human Rights Law Journal 11, 1990, p. 66.

${ }^{80}$ Opinión Consultiva OC-16/99, cit. nota n. 73, párr. 117.

${ }^{81}$ MAHONEY, "Judicial", cit. nota n. 79, pp. 66 \& 67.

${ }^{82}$ Sentencia de Fondo de la CtIDH, Villagrán-Morales y Otros Vs. Guatemala (Niños de la Calle), 19 de noviembre de 1999 (Ser. C) № 63, párr. 144.

${ }^{83}$ No sólo en lo que se refiere a las condiciones de vida, como ha señalado la Corte, sino que también al núcleo de su contenido: el derecho a mantenerse en vida.

${ }^{84}$ Establecido en arts. 11 y $5.1 \mathrm{CADH}$.

${ }^{85}$ Un ejemplo clásico es el de la Sentencia de la Corte Suprema de EE.UU., Roe Vs. Wade, 410 U.S. 113 (1973).
} 
el momento de la concepción. ${ }^{86}$ Además, según el Pacto de San José, el derecho a la vida no es un asunto privado, sino que uno por el que la legislación debe velar. Esto excluye cualquier duda que pudiera surgir en materia de la extensión del derecho a la privacidad en materia de aborto.

Además, para interpretar un tratado en forma evolutiva no basta con que algunos de sus términos sean ambiguos. Es también necesario que exista un fundamento adicional, como podría ser un cambio en las circunstancias debido a existencia de nuevos medios tecnológicos, o un consenso internacional en las obligaciones que emanan de un cierto derecho. En materia del no nacido, la primera fundamentación, podría dar pie para afirmar que los nuevos conocimientos en temas como el ADN del embrión, y la cada vez mayor reducción en los peligros asociados al embarazo, justificarían una interpretación evolutiva que potencie el derecho a la vida, haciendo más estrechas las excepciones aceptadas por la frase "en general". De igual modo, la fundamentación sobre el consenso internacional tampoco puede ser utilizada para restringir el derecho a la vida, pues las tendencias internacionales en esta materia no son necesariamente las de América del Norte o Europa Occidental. ${ }^{87}$ La normativa en materia de aborto no tiene una dirección absolutamente clara entre los Estados miembros de la OEA, ya que algunas se han vuelto más liberales, como en el caso del Distrito Federal de México o Colombia, ${ }^{88}$ pero otras se han vuelto más estrictas, como ha sucedido en el caso de Nicaragua, El Salvador y Chile. ${ }^{89}$ Estos argumentos sólo complementan los principales motivos

\footnotetext{
${ }^{86}$ En efecto, si en estas jurisdicciones se hubiera contemplado expresamente el derecho a la vida del no nacido, la solución habría sido distinta. Por ejemplo, en el caso Roe v. Wade la Corte Suprema de EE.UU. afirmó que: si la decimocuarta enmienda hubiera sugerido que el feto tenía personalidad jurídica, el caso de los apelantes colapsaría, ya que el derecho a la vida del no nacido habría estado garantizado específicamente por la Constitución. Ibíd., p. 157. Sin embargo, la Corte también afirmó que la palabra persona, según el modo en que estaba usada en la enmienda respectiva, no habría incluido al no nacido. Ibíd., p. 158.

${ }^{87} \mathrm{Sin}$ embargo, incluso en los EE.UU. la tendencia en materia de aborto no es clara, ya que el precedente de Roe Vs. Wade ha sido "aclarado" con casos como Sentencia de la Corte Suprema de EE.UU., Planned Parenthood of Southeastern Pa. Vs. Casey, 505 U.S. 833 (1992) y Sentencia de la Corte Suprema de EE.UU., Gonzales Vs. Carhart, 550 U.S. 124 (2007).

${ }^{88}$ Ver Ford, Allison, "Mexico City Legalizes Abortion". 2010. Law and Business Review of the Americas 16, pp. 119-127, y Sentencia de la Corte Constitucional (Colombia), C-355/06, 10 de mayo de 2006. En: http://www.corteconstitucional.gov.co/relatoria/2006/C-355-06.htm [visitado el 07/05/2011] [en adelante Sentencia de la Corte Constitucional Colombiana].

${ }^{89}$ En el caso de Nicaragua, la prohibición completa del aborto fue establecida recién el año 2006 mediante una ley que derogó el artículo 165 de su antiguo Código Penal, ley № 603, del 26 de octubre de 2006, Ley de Derogación al artículo 165 del Código Penal Vigente, La Gaceta, Diario Oficial [L.G.], 17 de noviembre de 2006. Esta prohibición fue mantenida en el nuevo Código Penal de Nicaragua de 2007. El Código Penal de El Salvador de 1997 terminó con la excepción a la penalización del aborto contemplada en el Código Penal de 1974 (Moreno Carrasco, Francisco y Rueda García, Luis, Código Penal de El Salvador Comentado. Vol. I, Consejo Nacional de la Judicatura, S.D., p. 531). Chile modificó el Código
} 
por los cuales no sería procedente una interpretación evolutiva en contra del no nacido, que ya fueron señalados en párrafos anteriores.

Por otra parte, algo similar sucede con las argumentaciones pro homine o pro persona, las que nunca pueden ser usadas en contra del texto de una convención. En efecto, la misma Corte Interamericana ha señalado que "el equilibrio de la interpretación se obtiene orientándola en el sentido más favorable al destinatario de la protección internacional, siempre que ello no implique una alteración del sistema". ${ }^{90}$ Además, estos principios pueden ser usados para extender un derecho, no para restringirlo. Por ejemplo, pueden utilizarse para argumentar que el derecho a estar libre de legislación retroactiva en materia penal se aplica también a legislación administrativa sancionatoria, pero no para restringir su uso sólo a cierta normativa penal. ${ }^{91}$

Sin perjuicio de lo anterior, alguno podría querer alegar el principio pro homine para afirmar que la mujer embarazada debería tener preferencia frente al no nacido. Sin embargo, el uso del principio pro homine es un arma de doble filo en el sistema interamericano, ya que puede afirmarse que tal principio no permite ningún tipo de abuso en contra de la persona, concepto que incluye al no nacido según la Convención Americana. Con ello, podría terminar prohibiéndose todo aborto directo. Esto puede ejemplificarse con la decisión del Tribunal Constitucional de Chile, que citando el uso del principio pro homine hecho por la Corte Interamericana, determinó que la píldora del día después no

Terapéutico el año 1989, terminando con la autorización para abortar cuando la vida de la madre se encontrara amenazada por el embarazo (art. 119 del Código Sanitario). Tanto la autorización de esta forma de aborto en 1931, como la reintroducción de su prohibición en 1989, fueron decididos sin un parlamento elegido popularmente. En efecto, en 1931 el Código Sanitario fue aprobado por el Congreso Termal, hecho a la medida durante la llamada dictadura de Carlos Ibáñez del Campo, y en el año 1989 las leyes eran aprobadas por la Junta de Gobierno. Asimismo, en Chile se promulgó hace pocos años una ley que protege la vida desde el momento de la concepción (art. 1, Ley № 20.120, "Sobre la Investigación Científica en el Ser Humano, su Genoma, y Prohíbe la Clonación Humana", 22 de septiembre de 2006), y la autorización de la distribución de la llamada píldora del día después se hizo sólo en el entendido -según dice la ley- de que tal método no causaría un aborto (art. 4º Ley № 20.418, "Fija Normas sobre Información, Orientación y Prestaciones en Materia de Regulación de la Fertilidad", 28 de enero de 2010). En el caso de Honduras, el Código Penal fue modificado en 1983 para permitir ciertas excepciones a la criminalización del aborto. Sin embargo, esa modificación fue derogada luego en 1985, antes de que la vacatio legis de tales excepciones hubiera concluido. UnITED NATIONS, Abortion Policies: A Global Review. Vol. II, United Nations Publications, Nueva York, 2001, p. 49. Respecto a los estados federados de México, ver la nota 45. En muchos casos la autorización del aborto no ha sido aprobada por los legisladores democráticamente electos, sino que por jueces, como en el caso de Colombia.

90 Sentencia que Declara Inadmisibilidad de la CtIDH, Asunto de Gallardo, Viviana y Otras, 13 de noviembre de 1981, (Ser. A) № G101/81, párr. 16. Sin énfasis en el original.

${ }^{91}$ Algo así se hizo en Sentencia de Fondo Reparaciones y Costas de la CtIDH, Baena et. al. Vs. Panamá, 2 de febrero de 2001, (Ser. C) № 72, párrs. 106 y 107, a pesar de que la Corte no hizo ninguna referencia explícita a una interpretación pro homine. 
podría ser distribuida en consultorios públicos. El razonamiento del Tribunal se basó en que, atendida la falta de claridad existente en la comunidad científica, existiría una duda razonable sobre si la vida comienza en la fecundación o en la implantación y, por tanto, uno de los efectos de la píldora del día después podría ser poner término a la vida de un ser humano. Según el Tribunal Constitucional, la aplicación del principio pro homine exigiría que, frente a esta duda razonable, el juzgador se inclinara en contra de una interpretación que pudiera poner término a la vida de una persona. ${ }^{92}$ Esta sentencia ha sido objeto de comentarios favorables y desfavorables. ${ }^{93}$ Un razonamiento similar, pero basado principalmente en el principio precautorio, puede verse en un fallo del año 2009 del Tribunal Constitucional de Perú. ${ }^{94}$

\subsection{Declaraciones interpretativas}

Al momento de votar el artículo 4.1, Brasil y los Estados Unidos decidieron introducir una declaración, escrita originalmente en inglés, que dice lo siguiente: "Los Estados Unidos y Brasil interpretan el lenguaje del párrafo 1 del artículo 4, como manteniendo la discreción de los Estados partes en relación con el contenido de la legislación a la luz de su propio desarrollo social, experiencia y factores similares".$^{95}$ Esta declaración busca conceder a ambos países la libertad para interpretar el derecho a la vida del modo que ellos consideren más apropiado. Atendido que ella se refiere en términos amplios al artículo 4.1, tal declaración se extendería no sólo al tema del comienzo de la personalidad, sino que también a cualquier otro asunto que se refiera al derecho a la vida, el más básico de todos los derechos. ${ }^{96}$ La amplia redacción de

\footnotetext{
${ }^{92}$ Sentencia del Excmo. Tribunal Constitucional que Acoge Parcialmente el Requerimiento de Inconstitucionalidad, 18 de abril de 2008, Sentencia 740-07-CDS, en páginas 118, 119 y especialmente 140-142. En http://www.tribunalconstitucional.cl/index.php/sentencias/download/pdf/914 [visitado el 12/08/11] (los números de página referidos son aquellos del documento en PDF disponible en el sitio web del Tribunal). Después de esta decisión, el Poder Legislativo modificó la ley para así permitir la distribución de la píldora del día después, entendiendo expresamente que este método no sería abortivo (ver nota n. 89).

${ }^{93}$ Algunos de los primeros pueden verse en VIVANCO, "La Píldora", cit. nota n. 26, y algunos de los segundos en Bordalí Salamanca, Andrés y Zúñiga AÑazco, Yanira, "Análisis del Fallo del Tribunal Constitucional sobre la Píldora del Día Después" Anuario de Derechos Humanos 5, 2009.

${ }^{94}$ Sentencia del Tribunal Constitucional (Perú), 16 de octubre de 2009, Exp. N‥ 02005-2009-PA/TC, párrs. 48-52. En: http://www.tc.gob.pe/jurisprudencia/2009/02005-2009-AA.html [visitado el 24/10/11].

${ }^{95}$ Secretaría General, cit. nota n. 63, p. 441. Traducido libremente por el autor. La versión original dice: "The United States and Brazil interpret the language of paragraph 1 of Article 4 as preserving to State Parties discretion with respect to the content of legislation in the light of their own social development, experience and similar factors".

${ }^{96}$ Se extendería a la protección de la vida por ley, al momento en el que la vida comienza y a la privación arbitraria de la vida.
} 
esta declaración de Brasil y los Estados Unidos les permitiría considerar que, a la luz de su propio "desarrollo social", no toda persona tiene derecho a que se respete su vida, cuestión que alcanzaría no sólo al no nacido. Los trabajos preparatorios no registran las reacciones de los demás Estados frente a esta declaración. Sin embargo, la importancia de esta manifestación es bastante limitada, ya que Estados Unidos no se ha hecho parte del Pacto, y Brasil no ratificó su declaración al momento de hacerse miembro de la Convención. ${ }^{97}$ Además, esta declaración carece de importancia para efectos interpretativos frente a los demás Estados miembros.

Casi treinta años después, México ratificó la Convención haciendo una declaración interpretativa que reza: "Con respecto al párrafo 1 del artículo 4, [México] considera que la expresión 'en general' [. . .] no constituye obligación de adoptar o mantener en vigor legislación que proteja la vida 'a partir del momento de la concepción' ya que esta materia pertenece al dominio reservado de los Estados". El texto de esta declaración no fija el nacimiento como límite a la libertad que este Estado reclama para "adoptar o mantener en vigor legislación que proteja la vida". Sin embargo, la intención de México al emitir esta declaración fue sólo afirmar que tendría libertad para legislar sobre el tema del aborto, no la de excluirse de la obligación de proteger la vida de personas ya nacidas. ${ }^{98}$ Por tanto, esta declaración debe ser interpretada como referida sólo al tema de la terminación del embarazo.

Según ya se ha afirmado, la intención del artículo 4.1 es reconocer la personalidad del no nacido desde el momento de la concepción, y de requerir a los Estados que protejan, como regla general, al nasciturus por ley. Por su parte, México estaría usando su declaración para mantener su autonomía para legislar en materia del no nacido. Así, la declaración de México buscaría cambiar el alcance de una obligación contenida en un tratado internacional, y cuando las declaraciones interpretativas están dirigidas a hacerlo, ellas cesan de ser declaraciones, pasando a ser reservas. ${ }^{99}$ Por lo tanto, aquella afirmación que México llama

\footnotetext{
${ }^{97}$ Brasil hizo una interpretación declarativa al momento de hacerse parte del Pacto de San José, pero ella no se refiere al artículo 4.1 de la Convención. El estatus jurídico de la antigua declaración de Brasil es un tema que va más allá del objeto de este trabajo. Sin embargo, debe tenerse presente que "[l]a reserva que se formule en el momento de la firma de un tratado que haya de ser objeto de ratificación, aceptación o aprobación, habrá de ser confirmada formalmente por el Estado autor de la reserva al manifestar su consentimiento en obligarse por el tratado. En tal caso se considerará que la reserva ha sido hecha en la fecha de su confirmación". Art. 23.2 CVDT.

${ }^{98}$ Ningún autor parece haber afirmado que la Convención podría permitir que los Estados adopten teorías como aquellas de Kuhse y Singer, a las que este trabajo se ha referido previamente. Ver nota n. 32.

${ }^{99}$ Fitzmaurice, "The Practical", cit. nota n. 57, p. 208. Cfr. BazÁN, Víctor, "Las Reservas a los Tratados Internacionales sobre Derechos Humanos, con Particular Énfasis en el Efecto de Aquellas Respecto de la Entrada en Vigencia de la Convención Americana sobre Derechos Humanos", 2000, lus et Praxis 6,
} 
"declaración", es en realidad una reserva, de modo que su contenido deberá ser evaluado una vez que un caso que la implique sea llevado ante la Corte. ${ }^{100}$ Algo como esto sucedió ante el Tribunal Europeo de Derechos Humanos en los casos Belilos Vs. Suiza y Loizidou Vs. Turquía, donde éste decidió acerca de la validez de una parte de las declaraciones de los dos países involucrados. ${ }^{101}$

"[E]l propósito perseguido por la Convención constituye un verdadero límite al efecto de las reservas que se le formulen", ${ }^{102}$ ya que "dichas reservas deben interpretarse en el sentido que mejor se adecúe a dicho objeto y fin". ${ }^{103}$ Por tanto, si la Corte Interamericana se ve enfrentada a la aplicación de esta "declaración", debiera analizar su amplitud y compatibilidad con el objeto y fin de la Convención, de acuerdo con la discreción que ha o no otorgado a los Estados en casos anteriores. ${ }^{104}$ La Corte también deberá tener en consideración que la declaración de México se refiere a lo que este mismo Estado ha llamado el

p. 191. Con relación a las reservas hechas a la Convención, ver Montalvo, Andrés E., "Reservations to the American Convention on Human Rights: A New Approach", 2001. American University International Law Review 16, y la obra recién citada de Víctor Bazán.

${ }^{100} \mathrm{El}$ art. 75 de la CADH establece que ella "sólo puede ser objeto de reservas conforme a las disposiciones de la Convención de Viena sobre Derecho de los Tratados, suscrita el 23 de mayo de 1969". En relación con el artículo 20 de la CVDT (titulado "Aceptación de las reservas y objeción a las reservas"), la Corte Interamericana ha afirmado que sólo su primer párrafo es aplicable. Opinión Consultiva de la CtIDH, El Efecto de las Reservas sobre la Entrada en Vigencia de la Convención Americana sobre Derechos Humanos (arts. 74 y 75), 24 de septiembre de 1982 (ser. A) 2/82, párrs. 27-35.

101 La Corte consideró que estas declaraciones eran inválidas. Sentencia del Tr. Eur. D.H., Belilos v. Switzerland, 132 Eur. Ct. H.R. (Ser. A) párrs. 51-60 (1988), y Sentencia del Tr. Eur. D.H., Loizidou v. Turkey 310 Eur. Ct. H.R. (ser. A) párrs. 15, 27, 89, 90 \& 95-98 (1995).

102 Opinión Consultiva CtIDH 3/83, cit. nota n. 22, párr. 65.

103 Ibíd.

${ }^{104}$ En un caso relativo a una reserva amplia en materia de pena de muerte la Corte "ha examinado y rechazado - por una parte- la eficacia de la reserva o declaración limitativa formulada por [un Estado], considerando que por su carácter excesivamente general resulta[ba] contraria al objeto y fin de la Convención, y supedita[ba] ampliamente el desempeño jurisdiccional de la Corte a las normas nacionales y a las decisiones de órganos internos, y en este sentido contra[venía] principios del Derecho internacional". Voto concurrente razonado del juez Sergio García Ramírez en Sentencia de Fondo, Reparaciones y Costas de la CtIDH, Hilaire, Constantine y Benjamin y otros Vs. Trinidad y Tobago, 21 de junio de 2002 (ser. C) $N^{\circ} 94$, párr. 2 (se omiten las notas al pie). Algunos jueces son contrarios a las reservas en materia de derechos no derogables de la Convención ( $v$.gr. Cançado Trindade se ha opuesto fuertemente a cualquier reserva en materia del derecho a la vida. Cfr., Sentencia de Fondo, Reparaciones y Costas de la CtIDH, Caesar Vs. Trinidad y Tobago, 11 de marzo de 2005 (ser. C) № 123, párr. 23). El Comité de Derechos Humanos de las Naciones Unidas [CDHNU] tiene una opinión similar en materia de reservas. CDHNU, General Comment $\mathrm{N}^{\circ} 24$ : Issues relating to reservations made upon ratification or accession to the Covenant or the Optional Protocols thereto, or in relation to declarations under article 41 of the Covenant, 11 de abril de 1994, párrs. 6-12. En: http://www.unhchr.ch/tbs/doc.nsf/\%28Symbol\%29/69c55b086f72957ec12563 ed004ecf7a? Opendocument [visitado el 10/08/11]. Montalvo considera que la declaración mexicana es compatible con la Convención. Montalvo, "Reservations", cit. nota n. 99, pp. 293 \& 295. 


\begin{abstract}
"derecho más fundamental". ${ }^{105}$ En cualquier caso, esta declaración podría tener efectos sólo respecto de México, no pudiendo ser usada como una herramienta de interpretación de la Convención misma.
\end{abstract}

\title{
2. INTERPRETACIÓN DADA POR LA COMISIÓN
}

Hasta el momento la Corte no ha expresado su posición en el tema del no nacido, pero la Comisión lo ha hecho en algunas ocasiones al decidir sobre peticiones particulares, y al emitir algunas recomendaciones a los Estados. En estas últimas, la Comisión ha adoptado una posición contraria a leyes que prohíben todo tipo de aborto directo, ${ }^{106}$ lo que probablemente ha influido en

\footnotetext{
${ }^{105}$ Opinión Consultiva CtIDH 16/99, cit. nota n. 73, párrs. 26.

106 V.gr. CmIDH, Tercer Informe sobre la Situación de los Derechos Humanos en Colombia, OEA/ Ser.L/V/II.102 Doc. 9 rev. 1 (26/02/99), Cap. XII, párrs. 49-51, en: http:/www.cidh.oas.org/countryrep/ Colom99sp/indice.htm [visitado el 30/01/11]. En CmIDH, Quinto Informe sobre la Situación de los Derechos Humanos en Guatemala, OEA/Ser.L/V/II.111, doc. 21 rev. (06/04/01), párr. 39 del Cap. XIII, en: http://www.cidh.oas.org/countryrep/Guatemala01sp/indice.htm [visitado el 24/10/11], la Comisión parece evaluar negativamente la prohibición del aborto en dicho país, donde sólo se permite la terminación del embarazo en casos en que sea indispensable para salvar la vida de la madre. La posición de la $\mathrm{CmIDH}$ en relación al aborto también se desprende de aquellos documentos en que no hay ninguna consideración negativa sobre las restricciones a las terminaciones del embarazo, pero en los cuales esta entidad se refiere al aborto entre los derechos de la mujer, v.gr.: $\mathrm{CmIDH}$, Acceso a Servicios de Salud Materna desde una Perspectiva de Derechos Humanos, OEA/Ser.L/V/II, Doc. 69, (07/06/10), párr. 42, al afirmar que en sus visitas in situ se refirió al aborto como un problema muy serio para las mujeres, "no sólo desde un punto de vista de salud, sino también de sus derechos humanos a la integridad y a la privacidad", en: http://cidh.org/women/SaludMaterna10Sp/SaludMaterna2010.pdf [visitado el 17/06/11]; CmIDH, Observaciones de la Comisión Interamericana de Derechos Humanos sobre su visita a Haití en abril de 2007, OEA/Ser.L/V/II.131, doc. $36(02 / 03 / 08)$ al referirse a un proyecto de ley de Haití en materia de aborto, párr. 53, en: http://www.cidh.org/pdf\%20files/April\%202007\%20Haiti\%20 observations\%20SPN.pdf [visitado el 17/06/11]; CmIDH, Informe Anual de la comisión Interamericana de Derechos Humanos 2006, OEA/Ser.L/V/II.127, Doc. 4 rev. 1, (03/03/07), párr. 126, en: http://www. cidh.oas.org/annualrep/2006sp/cap4c.2006.sp.htm [visitado el 18/06/11], refiriéndose a la posible presentación de un proyecto de ley que despenalizaba el aborto en Haití; $\mathrm{CmIDH}$, Acceso a la Justicia para las Mujeres Víctimas de Violencia en las Américas, OEA/Ser.L/V/II, Doc. 68 (20/01/07), párrs. 254 \& 255, en: http://www.cidh.oas.org/pdf\%20files/Informe\%20Acceso\%20a\%20la\%20Justicia\%20 Espanol\%20020507.pdf [visitado el 18/06/11], afirmando que la Sentencia de la Corte Constitucional de Colombia -que puso término a una prohibición total del aborto- habría estado "encaminad[a] a proteger los derechos de las mujeres", y CmIDH, Informe Anual de la Comisión Interamericana de Derechos Humanos 1992-1993, OEA/Ser./L/V/II.83, doc. 14 (12/03/93), Cap. V, Situación de los Derechos Humanos de la Mujer en el Hemisferio, bajo el título Costa Rica, en: http://www.cidh.oas. org/annualrep/92span/cap.5f.htm [visitado el 18/06/11], que incluye en una lista de mejoras en los derechos de las mujeres, un proyecto de ley que permitiría el aborto en caso de violación. También debe notarse que las reglas en materia de aborto están consideradas como un indicador para evaluar la igualdad en materia del derecho a la salud, $\mathrm{CmIDH}$, Lineamientos para la Elaboración de Indicadores de Progreso en Materia de Derechos Económicos, Sociales y Culturales, OEA/Ser.L/V/II.132, Doc. 14 (19/07/08), tabla que aparece a continuación del párr. 93, en: http://www.cidh.oas.org/pdf\%20files/ Lineamientos\%20final.pdf [visitado el 18/06/11].
} 
cierta legislación interna de Estados miembros de la Convención. ${ }^{107}$ Sin embargo, estas recomendaciones generales no entregan mayores detalles sobre cómo la Comisión ha arribado a sus conclusiones, o cuál es el rol jugado por el artículo 4.1 en las decisiones de dicho organismo. Por lo tanto, este estudio se referirá principalmente a las afirmaciones que ha hecho la Comisión en casos particulares, ya que es ahí donde ésta ha dado mayor razón de sus dichos.

\subsection{Caso "Baby Boy"}

El caso "Baby Boy" se refiere a una petición presentada en contra de los Estados Unidos ante la Comisión Interamericana. ${ }^{108}$ Tal Estado es miembro de la OEA, pero no se encuentra bajo la jurisdicción de la Corte Interamericana -aunque durante el tiempo en que el caso "Baby Boy" fue analizado, dicha nación consideró la posibilidad de ratificar la Convención-. ${ }^{109}$ Atendido que la OEA ha puesto a la Comisión a cargo de "promover la observancia y la defensa de los derechos humanos y de servir como órgano consultivo de la Organización" en tales asuntos, este organismo pudo dedicarse a conocer este caso. ${ }^{110}$ En "Baby Boy" la Comisión afirmó su competencia para aplicar la Declaración Americana como Derecho sustantivo a todos los Estados miembros de la OEA. ${ }^{111}$

\footnotetext{
${ }^{107}$ V.gr. CmIDH, Tercer Informe (cit. nota n. 106), fue esgrimido como argumento durante el caso seguido ante la Corte Constitucional Colombiana que puso término a la prohibición absoluta del aborto directo, considerándolo aceptable en ciertas circunstancias. En este caso, el informe de la Comisión es usado entre los argumentos del Procurador General de la Nación, quien solicitó a la Corte que mantuviera la prohibición del aborto, pero que lo permitiera en ciertos casos excepcionales (la decisión se refiere erradamente al Comité Interamericano de Derechos Humanos) (Sentencia de la Corte Constitucional Colombiana, cit. nota n. 88, en 177 y 178. Los números de páginas citados en este artículo son aquellos del documento subido a la página web de esta Corte Constitucional). El informe es también mencionado en los salvamentos y aclaraciones de voto de los jueces Monroy y Escobar (el primero es el mismo que emitió un voto disidente en el caso Baby Boy, que se describirá en seguida), Cepeda, y Tafur (Ibíd., pp. 562, 395 y 655, respectivamente).

${ }_{108}$ Informe de la CmIDH, Fondo, Estados Unidos de América, № 23/81, Caso 2141, 1981. En: http:// www.cidh.org/annualrep/80.81sp/EstadosUnidos2141.htm [visitado el 30/01/11]. En adelante: caso "Baby Boy".

${ }^{109}$ Ver Alston, cit. nota n. 26, p. 176, y caso "Baby Boy", párr. 1.

110 Art. 106, Carta de la OEA. Uno de los poderes de la Comisión es "formular recomendaciones a los gobiernos de los Estados para que adopten medidas progresivas en favor de los derechos humanos. OEA, Estatuto de la Comisión Interamericana de Derechos Humanos (1979), art. 18.b.

${ }^{111}$ Shelton, "Abortion", cit. nota n. 23, p. 313. Más aún, la Corte Interamericana ha sostenido que, para los Estados miembros de la OEA, "la Declaración es el texto que determina cuáles son los derechos humanos a que se refiere la Carta [de la OEA]. De otra parte, los artículos 1.2.b) y 20 del Estatuto de la Comisión definen, igualmente, la competencia de la misma respecto de los derechos humanos enunciados en la Declaración. Es decir, para estos Estados la Declaración Americana constituye, en lo pertinente y en relación con la Carta de la Organización, una fuente de obligaciones internacionales". Opinión Consultiva OC-10/89, cit. nota n. 73, párr. 45.
} 
Los hechos de este caso son los siguientes: en 1973 una corte de Massachusetts halló culpable de homicidio sin premeditación a un médico que, previa solicitud de la madre, practicó el aborto "de un niño que reunía las condiciones relativas a la 'excepción protegible' (más de seis meses después de la concepción y/o vivo fuera del vientre) señalada por la Corte Suprema de los Estados Unidos en las causas de Wade y Bolton". ${ }^{112}$ La Corte Suprema de Massachusetts, en un recurso judicial, anuló posteriormente tal sentencia por las siguientes causales: prueba insuficiente sobre la temeridad del doctor y sobre su creencia de que el feto era viable, prueba insuficiente de vida fuera del vientre de la madre, y error de procedimiento. ${ }^{113}$ Los peticionarios consideraron que esta decisión violaba la Declaración Americana de los Derechos y Deberes del Hombre. No hubo controversia respecto de los hechos del caso. ${ }^{114}$

Distintos asuntos sobre admisibilidad fueron discutidos en este caso, pero se ignoró el fundamental tema de si el nasciturus "Baby Boy", a cuyo nombre se presentaba la petición, era una persona para efectos jurisdiccionales. ${ }^{115}$ "Simplemente se tomó como verdad el que una 'persona' había sido sujeta a una supuesta violación, dejando abierta la posibilidad de que otros casos de daño fetal o muerte fueran presentados sobre la base de este precedente jurisdiccional".116 Esto hace pensar que "el feto es una 'persona' para efectos jurisdiccionales".117 Algo similar habría ocurrido con un caso individual seguido contra Canadá en materia de libertad de expresión de un activista pro-vida. ${ }^{118}$ Mas aún, en su demanda en el caso Xákmok, al momento de indicar quiénes son los miembros difuntos de la Comunidad, la Comisión califica a cada uno de los niños no nacidos como "persona" fallecida. ${ }^{119}$

\footnotetext{
112 Caso "Baby Boy", párr. 3(d).

113 Ibíd.

114 Ibíd., "Considerando", párr. 7.

${ }^{115}$ Shelton, "Abortion", cit. nota n. 23, p. 312.

116 Ibíd. Traducido libremente por el autor.

117 Ibíd. Traducido libremente por el autor.

${ }^{118}$ En esta petición se reclamó también por la violación de los derechos de niños no nacidos y sus madres. Estas últimas reclamaciones fueron consideradas inadmisibles, pero no porque los no nacidos no fueran personas, sino porque la Comisión dijo que las peticiones no debían ser entendidas como actio popularis, y que, por ello, no debían presentarse in abstracto. Informe de la CmIDH, Admisibilidad, James Demers, Canadá, № 85/06, Petición 225-04, 2006, párrs. 41 \& 42. En http://www.cidh. org/annualrep/2006sp/canada225.04sp.htm [visitado el 30/01/11].

${ }^{119}$ Esto lo hizo siguiendo la información entregada por los representantes de la Comunidad Indígena. Sin embargo, al hacerlo, este organismo habría secundado las solicitudes de Xákmok Kásek en materia del no nacido. Ver Demanda de la $\mathrm{CmIDH}$ ante la Corte Interamericana De Derechos Humanos, caso Comunidad indígena Xákmok Kásek del pueblo Enxet-Lengua y sus miembros (Caso 12.420) contra la República del Paraguay, 3 de julio de 2009, párr. 105. En: http://www.cidh.oas.org/demandas/12.420\%20 Xakmok\%20Kasek\%20Paraguay\%203jul09\%2 0ESP.pdf [visitado el 30/01/11].
} 
Esto podría ser interpretado no sólo como un conceder personalidad para efectos jurisdiccionales, sino que también para efectos de ser titular de algunos derechos consagrados en la Convención.

En el caso "Baby Boy", la Comisión analizó la Declaración y la Convención a la luz de sus trabajos preparatorios, pero no dio mayor importancia a otros métodos de interpretación para apreciar el sentido de tales instrumentos internacionales, en particular el de la Convención. La Comisión concluyó, por cinco votos contra dos, que la decisión de la Corte Suprema de Massachusetts no violó la Declaración Americana. ${ }^{120}$ La explicación más probable para esta decisión viene dada por el texto de la Declaración, que permite una interpretación más flexible del derecho a la vida que el de la Convención. ${ }^{121}$ En efecto, un borrador previo de la Declaración solía tener una referencia explícita al "derecho a la vida desde el momento de la concepción; al derecho a la vida de los incurables, imbéciles y dementes", pero esta referencia fue suprimida, sin que los trabajos preparatorios expliquen los motivos de esta modificación. ${ }^{122}$ Las dos opiniones disidentes manifestaron que la Declaración sí buscaba proteger la vida desde el momento de la concepción. ${ }^{123}$

\footnotetext{
${ }^{120}$ Entre la mayoría se encontraba el voto del relator que, sin mayor éxito, recomendó excluir de la Convención la referencia a la concepción. General SeCRetariat, Anuario Interamericano, cit. nota n. 28, p. 193.

121 Por ejemplo, guarda silencio en materia de la pena de muerte. La prohibición de la imposición de "penas crueles, infamantes o inusitadas" (art. XXVI) no pretendía incluir la pena de muerte.

${ }^{122}$ Shelton, "Abortion", cit. nota n. 23, pp. 313 \& 314. De modo similar, el Dr. Tinoco argumenta en su opinión disidente del caso "Baby Boy": "No encuentro [...] ninguna explicación específica de las razones que motivaron la eliminación de la frase complementaria que contiene el Proyecto de Declaración de los Derechos y Deberes Internacionales del Hombre presentado por el Comité Jurídico Interamericano (Documento CB-7) y que reconoce el 'derecho a la vida, inclusive (a) los que están por nacer, así como también (a)los incurables, dementes y débiles mentales'. Por lo que debo deducir que la razón de esa eliminación no fue otra que la que expresa el Relator señor López de Mesa en estos términos: Asimismo se dispuso redactarlos (los derechos y deberes) en su mera esencia, sin enumeraciones- ejemplares $\mathrm{O}$ taxativas, que llevan consigo el riesgo de la difusión inútil y de la confusión peligrosa de sus límites". (subrayado en el original). Caso "Baby Boy", Voto Negativo del Dr. Luis Demetrio Tinoco Castro, tercer párrafo. La posición de la mayoría en el caso "Baby Boy" está en desacuerdo con esta afirmación, ya que argumenta que fue modificado para hacerlo compatible con las legislaciones internas que regulaban el aborto y la pena de muerte (caso "Baby Boy", Considerando 19). Sin embargo, esta afirmación no explica por qué se eliminó también la referencia a los incurables, imbéciles y dementes. Asimismo, si los redactores de la Convención buscaban hacer la Declaración compatible con la legislación nacional que autorizaba la pena de muerte, Ilama la atención que hayan eliminado, justamente, la excepción explícita que el proyecto establecía en los siguientes términos: "La pena capital puede aplicarse únicamente en casos en que se haya prescrito por leyes pre-existentes por delitos de extrema gravedad" (Cfr. Ibíd. letra (b)). En efecto, la redacción actual contiene una formulación absoluta del derecho a la vida. Esto muestra que las razones para la reformulación del artículo $1^{\circ}$ de la Declaración no son tan sencillas como la Comisión las presenta, y no parecen estar claras en los trabajos preparatorios.

${ }^{123}$ Votos negativos de los comisionados Marco Gerardo Monroy Cabra y Luis Demetrio Tinoco Castro.
} 
La Comisión también afirmó, en una especie de obiter dictum, que la oración "en general, a partir del momento de la concepción", no buscaba reflejar "que quienes formularon la Convención tuviesen la intención de modificar el concepto de derecho a la vida que prevaleció en Bogotá, cuando aprobaron la Declaración Americana". ${ }^{124}$ Este obiter dictum es contrario a lo que sostuvo previamente el comisionado Tom J. Farer -quien estaba entre la mayoría- al dar su testimonio sobre el Pacto de San José ante el Congreso estadounidense el año 1979, donde afirmó que "Estados Unidos debería rehusarse a aceptar la preclusión categórica del aborto que hace el artículo cuatro". ${ }^{125}$ De igual modo, el comisionado Andrés Aguilar no parece haber querido referirse a la Convención, ya que él emitió una opinión concurrente en la que recalcó que él alcanzaba su decisión sólo porque los Estados Unidos no debían ser juzgados a la luz de la Convención, sino sólo de la Declaración, la que permitiría que cada Estado regulara el tema de la protección de la vida antes del parto. ${ }^{126}$ Él también se preocupó de afirmar que "la vida del ser humano comienza en el momento mismo de la concepción y debería merecer desde este momento plena protección, tanto en el derecho interno como en el internacional". ${ }^{127}$

\subsection{Otros casos}

Un caso más reciente relacionado al aborto es Paulina del Carmen Ramírez Jacinto contra México. ${ }^{128}$ Los peticionarios de este caso fueron algunas ONG que alegaron la violación de varios artículos de ciertas convenciones internacionales. Los hechos se refieren a una menor embarazada como consecuencia de una violación. Ella, con el consentimiento de su madre, buscó abortar de acuerdo con las leyes del Estado de Baja California, pero muchos obstáculos fueron opuestos a la realización de este acto autorizado por la ley. Esto trajo como consecuencia que ella dio a luz a su hijo Isaac de Jesús. Los asuntos jurídicos involucrados en esta petición son similares a los de los casos Tysiac Vs. Polonia, y $A, B \& C$ Vs. Irlanda, seguidos ante el Tribunal Europeo de Derechos Humanos. ${ }^{129}$

\footnotetext{
124 Caso "Baby Boy", Considerando 30.

${ }^{125}$ Citado en ALSTON, "The Unborn", cit. nota n. 26, pp. 176-177. Traducido libremente por el autor. El destacado es nuestro.

${ }^{126}$ Caso "Baby Boy", opinión concurrente del Dr. Andrés Aguilar M., párrs. 4, 5 y, particularmente, 7.

127 Ibíd. párr. 8.

128 Informe de la CmIDH, Solución Amistosa, Paulina del Carmen Ramírez Jacinto, México, № 21/07, Petición 161-02, 2007. En: http://www.cidh.org/annualrep/2007sp/Mexico161.02sp.htm [visitado el 30/01/11].

${ }^{129}$ Sentencia del Tr. Eur. D.H., Tysiac v. Poland, 2007, App. № 5410/03 y Sentencia del Tr. Eur. D.H., A, B \& C v. Ireland, 2010, App. № 25579/05. Para un análisis de la jurisprudencia del Tribunal Europeo
} 
México y Paulina Ramírez pusieron término a este caso mediante un acuerdo. Según éste, el Estado reconoció su responsabilidad por no implementar un procedimiento adecuado que permitiera a las mujeres procurarse aquellos abortos autorizados por la ley; accedió a crear e implementar estos procedimientos, y acordó pagar una compensación económica a Paulina Ramírez y a su hijo. ${ }^{130}$ Es importante destacar que este caso no se refiere al tema de si el aborto directo es o no aceptado o requerido por la Convención, sino que a la procedencia de oponer obstáculos a la realización de abortos ya autorizados por la ley. Por lo tanto, la Comisión no desarrolló explícitamente su doctrina sobre el estatus del no nacido. ${ }^{131}$

El 26 de febrero de 2010 la Comisión Interamericana emitió una medida cautelar en el caso "Amelia", en contra de Nicaragua. ${ }^{132}$ Este asunto se refirió a una mujer a quien se le negó la atención médica necesaria para tratar un cáncer, en atención a que la práctica de una quimioterapia o radioterapia podrían provocar un aborto. La Comisión solicitó al Estado que adoptara dentro de cinco días las medidas necesarias para asegurar que la interesada tuviera acceso al procedimiento médico, frente a lo cual Nicaragua informó a la Comisión que ya se habría iniciado el tratamiento requerido. Este es un caso en el que los médicos de Nicaragua se habrían negado a practicar una intervención legal, ya que, aunque la legislación de este Estado prohíbe toda forma directa de terminación del embarazo, los abortos producidos como consecuencia de un tratamiento curativo indispensable y urgente para salvar la vida de la madre se hallan permitidos por la ley. Este estudio se referirá más adelante a la distinción entre los abortos directos e indirectos.

El informe más reciente sobre el no nacido respondió a algunas peticiones que reclamaban en contra de la prohibición costarricense de la fecundación in vitro. ${ }^{133}$ Tal restricción fue establecida mediante un fallo de la Corte Suprema de Costa Rica, que consideró que el actual estado de desarrollo de dicha técnica implicaba la muerte de un número elevado de embriones, constituyendo un

en esta materia ver: DíAz de VALdés J., José Manuel, "Análisis Crítico de la Jurisprudencia de la Corte Europea de Derechos Humanos sobre el Estatus del No Nacido en la Convención Europea de Derechos Humanos". 2008. Actualidad Jurídica 18.

${ }^{130}$ El texto del reconocimiento público de responsabilidad está anexado al Informe $N^{\circ} 21 / 07$, cit. nota n. 128.

${ }^{131}$ La Comisión hace referencia a los derechos de las mujeres y a la Convención de Belém do Pará, pero no hace ninguna afirmación con relación al aborto. Ibíd. párr. 19.

132 Informe de la CmIDH, Medida Cautelar, "Amelia", Nicaragua, MC № 43/10, 2010 CmIDH. En: http://www.cidh.org/medidas/2010.sp.htm [visitado el 24/10/11].

${ }^{133}$ Informe de la CmIDH, Fondo, Gretel Artavia Murillo y Otros (Fertilización in vitro), Costa Rica, $N^{\circ}$ 85/10, Caso 12.361, 2010 CmIDH. En: http://www.asamblea.go.cr/Centro_de_informacion/biblioteca/Documentos\%20compartidos/TA-FIV/Costa\%20Rica/l85-10.pdf [visitado el 08/09/11]. 
atentado al derecho a la vida. ${ }^{134}$ Es interesante considerar que el juez que redactó la opinión de la Corte Suprema de Costa Rica fue Rodolfo Piza Escalante, un ex Presidente del Tribunal Interamericano, quien consideró que este fallo estaba de acuerdo con el Pacto de San José.

La Comisión interamericana decidió que tal sentencia violaba los derechos establecidos en los siguientes artículos de la Convención: 11.2 (a la vida privada y familiar), 17.2 (a fundar una familia) y 24 (igualdad ante la ley e igual protección de la ley), en relación con las obligaciones de carácter general establecidas en los artículos 1.1 y $2 .{ }^{135}$ El recién referido informe no analizó el contenido del artículo 4.1, a pesar de que la defensa de Costa Rica se basó principalmente en dicha norma. En efecto, en este punto la Comisión sólo hizo presente que "el Estado tenía un fin legítimo en términos generales consistente en proteger un bien jurídico tutelado como es la vida". ${ }^{136}$

La Comisión estudió en detalle si la prohibición de Costa Rica violaba los derechos establecidos en los artículos 11, 17 y 24. Al analizar si la restricción de los dos primeros derechos era adecuada, este organismo señaló que la prohibición de la fecundación in vitro cumplía con los requisitos de legalidad, fin legítimo e idoneidad, pero que "existían formas menos restrictivas para satisfacer el objetivo buscado por el Estado y acomodar los intereses en juego". ${ }^{137}$ Para decidir esto, la Comisión tuvo en consideración que Costa Rica, si bien no es la única nación del Continente en proteger al embrión, es la única que prohíbe técnica in vitro. ${ }^{138}$ Con relación al artículo 24, la Comisión afirmó que la decisión de dicho Estado: “i) impidió a las víctimas superar la situación de desventaja en la que se encontraban a través del beneficio del progreso científico, en particular, de un tratamiento médico; y ii) tuvo un impacto específico y desproporcionado frente a las mujeres". ${ }^{139}$ La decisión sobre este último artículo fue objeto de tres

\footnotetext{
${ }^{134}$ Ver nota n. 44, especialmente el Considerado IX. La Corte Suprema también afirmó que "El embrión humano es persona desde el momento de la concepción". Ibíd. Considerando IX.

${ }^{135}$ Gretel Artavia Murillo y Otros (Fertilización in vitro), cit. nota n. 133, párr. 5.

136 Ibíd., párr. 96.

137 Ibíd., párr. 110.

138 Ibíd., párr. 100. La Constitución del estado mexicano de Nayarit contiene una norma que "reconoce, protege y garantiza el derecho a la vida de todo ser humano desde el momento de la fecundación natural o artificial" (el destacado es nuestro). El autor de este artículo no tiene información sobre si esta disposición tiene algún impacto en la fecundación in vitro. Estado mexicano de Nayarit, Const. art. $7^{\circ}$ (XIII)(1)(2010). Esta referencia a la fecundación fue introducida en una reforma constitucional de 2009. Respecto al tema de un amplio consenso en una determinada materia, la Corte Europea ha señalado, al autorizar la amplia protección de la vida del no nacido en Irlanda, que "el consenso no puede ser un factor decisivo en el examen que haga la Corte". Sentencia del Tr. Eur. D.H., A, B \& C v. Ireland, 2010, App. № 25579/05, párr. 237. Traducido libremente por el autor.

${ }^{139}$ Gretel Artavia Murillo y Otros (Fertilización in vitro), cit. nota n. 133, párr. 128.
} 
votos disidentes, incluido el del Presidente y de la Segunda Vicepresidenta de la Comisión. Como puede observarse, este informe no explica en detalle la lectura que hace la Comisión Interamericana del artículo 4.1, pero demuestra que este organismo no aceptaría leyes que, esgrimiendo como justificación la defensa del no nacido, prohíban la realización de acciones ampliamente aceptadas entre los Estados de América.

Después de ser notificado de este informe, el Gobierno de Costa Rica presentó un proyecto de ley que buscaba evitar la presentación de una demanda ante la Corte. ${ }^{140}$ Esta moción permitía las fecundaciones in vitro, pero contenía una regulación muy particular de tal procedimiento, la que buscaba compatibilizarlo con la posición histórica de Costa Rica en materia del derecho a la vida. ${ }^{141}$ Sin embargo, este proyecto fue rechazado por el Congreso costarricense, por lo que la Comisión presentó este caso ante el tribunal interamericano. ${ }^{142} \mathrm{~A}$ pesar de lo dispuesto en el texto de la Convención, este caso presenta ciertas características que facilitarían una decisión favorable a la Comisión, ${ }^{143}$ pero no es fácil predecir qué doctrina sentará la Corte en materia de la personalidad del no nacido. En todo caso, la decisión de la Corte tendría que tener efectos distintos a los de otros tratados de derechos humanos, como el de la Convención Europea, ya que de otro modo la referencia al momento de la concepción no tendría ningún efecto relevante.

\subsection{Posición General de la Comisión}

La Comisión parece conceder personalidad al no nacido para efectos jurisdiccionales, como puede observarse en dos peticiones presentadas ante

\footnotetext{
${ }^{140}$ Esta información está disponible en el siguiente artículo electrónico de prensa del periódico Al Día, Estados Unidos, 22/10/10, en: http://www.pontealdia.com/america-latina/costa-rica-presenta-ley-defecundacion-in-vitro-para-evitar-juicio.html [visitado el 30/01/11].

${ }^{141}$ Esta postura también fue expresada durante la redacción de la Convención. En dicho momento Costa Rica se opuso fuertemente a la pena de muerte. Al hacerlo, tal nación se abstuvo de votar la parte relevante del artículo correspondiente, para así manifestar su deseo de que todos los demás Estados abolieran este tipo de penas (SeCRETARía General, cit. nota n. 63, p. 162). Costa Rica también afirmó "man[tener] inquebrantable adhesión al principio de la inviolabilidad de la vida humana" y su no aceptación de "preceptos que no tiendan a garantizar, en forma absoluta, ese sagrado principio". Ibíd. p. 441.

${ }^{142}$ Esta información está disponible en la siguiente noticia: CIDH ya demandó al país ante Corte Interamericana por fecundación in vitro, ElPaís.cr, 01/08/11, Costa Rica, en http://www.nacion.com/201108-01/EIPais/CIDH-ya-demando-al-pais-ante-Corte-Interamericana-por-fecundacion-in-vitro.aspx [visitado el 10/08/11].

${ }^{143}$ Las características que facilitarían acoger la demanda son: que el juez Ventura Robles, el único de los jueces actuales que se ha referido a los derechos desde el momento de la concepción en una sentencia previa, no podrá tomar parte en esta decisión por ser un nacional del Estado demandado (art. 19.1 Reglamento de la $\mathrm{CtIDH}$ ); que la fertilización in vitro es ampliamente aceptada en el continente americano, por lo que exigir su implementación no requeriría que otros Estados modifiquen su legislación, y que la muerte de embriones no da origen a las mismas reacciones negativas que el aborto directo.
} 
ella. ${ }^{144}$ Asimismo, este organismo parece apoyar la capacidad del no nacido de ser lesionado por terceros. ${ }^{145}$ Sin embargo, la Comisión otorgaría a los Estados un amplio margen de apreciación para determinar la protección que conceden al no nacido. Esta discrecionalidad tendría algunas excepciones, como se observa en recomendaciones generales, en algunos informes de país y en el caso contra Costa Rica. En efecto, la Comisión no aceptaría leyes que prohíban la realización de acciones ampliamente aceptadas entre los Estados de América, como sucede con la fertilización in vitro y los abortos en situaciones excepcionales y graves, v.gr. cuando la vida de la madre está en riesgo. Hasta el momento, la Comisión no ha explicado suficientemente en sus informes de país cuál es el fundamento por el cual ha recomendado a los Estados terminar con la prohibición total de abortos. ${ }^{146}$

En cualquier caso, la opinión de la Comisión no es concluyente, ya que es la Corte la que tiene el mayor poder para fijar las interpretaciones definitivas de instrumentos internacionales en el sistema interamericano. Al hacerlo, dicho tribunal no puede simplemente tomar prestadas las interpretaciones de la Convención que hace la Comisión, puesto que la Corte suele considerar a la Comisión como un organismo que sólo le propone argumentos, no como una fuente independiente de interpretación de tales normas. ${ }^{147}$ En efecto, no es poco frecuente que la Corte rechace alegaciones jurídicas de la Comisión, entre las que se hallan algunas interpretaciones del Pacto de San José. ${ }^{48}$

\section{Alcance de la expresión "en General"}

Este artículo ha mostrado la intención de la Convención de reconocer personalidad al ser humano desde el momento de la concepción, y de requerir al Estado que proteja por ley, como regla general, la vida del no nacido. Hasta el momento, este trabajo no ha interpretado cuál es el significado de la expresión "en general". Antes de hacerlo, debe considerarse que, cuando la Convención sostiene que excepcionalmente la vida no estará protegida por ley, no está afirmando que el Estado no tenga la obligación de proteger la vida a través de

\footnotetext{
${ }^{144}$ Caso "Baby Boy" y James Demers, cit. nota n. 118.

145 Según se desprende de la demanda correspondiente del caso Xákmok.

${ }^{146}$ La Comisión sólo se refiere al aborto como consecuencia de los derechos a la integridad personal y a la privacidad, pero no hace un análisis que incluya consideraciones sobre otros artículos de la Convención, particularmente sobre la referencia al concebido en el artículo referido al derecho a la vida.

147 Neuman, Gerald L., "Import, Export and Regional Consent in the Inter-American Court of Human Rights", European Journal of International Law 19, 2008, p. 108.

${ }^{148}$ E.g. Opinión Consultiva de la CtIDH, La Colegiación Obligatoria de Periodistas (arts. 13 y 29 Convención Americana sobre Derechos Humanos), 13 de noviembre de 1985 (Ser. A) 5/85.
} 
otras acciones, v.gr. administrativas. En efecto, el Estado debe proteger la vida siempre, en gran medida a través de acciones dirigidas a garantizar la salud de la madre embarazada. La interpretación del artículo 4.1 que se propone a continuación, se referirá principalmente al tema del aborto y su prohibición, ya que éste es el más controversial en relación con esta norma.

\subsection{Cuestión preliminar}

Algunos pueden sostener que la prohibición del aborto no es necesaria para proteger la vida por ley y, en general, desde el momento de la concepción. Podría afirmarse que existen mecanismos alternativos para proteger la vida. Un asunto similar fue analizado por el Tribunal Constitucional Federal Alemán al efectuar el control constitucional abstracto de dos proyectos de ley, uno en 1975 y otro en 1993. ${ }^{149}$ Tal tribunal consideró que la Ley Fundamental Alemana permitía al legislador definir las circunstancias en las cuales una mujer no debía ser obligada a dar a luz, pero determinó, en 1993, que el estándar mínimo de protección requería que la interrupción del embarazo durante todo el tiempo que dure éste, fundamentalmente debe ser considerada como antijurídica, y que, por tanto, está prohibido jurídicamente (cf. BVerfGE 39,1 [44]). Si no existiera una prohibición de este tipo, se estaría entregando la posibilidad de disponer del derecho a la vida del nasciturus -aunque fuera sólo por un tiempo limitado- a la decisión libre y no vinculada jurídicamente de un tercero -aun cuando se trate de la madre misma-; con ello, no se estaría garantizando la protección legal de esa vida de conformidad con los requisitos de conducta citados anteriormente. ${ }^{150}$

La Corte Constitucional Federal Alemana consideró que el proceso de liberalizar legislaciones de aborto restrictivas -sin importar qué tan humanas puedan ser sus motivaciones-, es usualmente interpretado como una autorización para

\footnotetext{
149 Bundesverfassungsgericht [BVerfG] [Corte Constitucional Federal], 1975, 39 ENTSCHEIDUNGEN DES BundesVerfassungsGerichts [BVerfGE] [Decisiones de la Corte Constitucional Federal (Gaceta Jurídica)] 1, y BVerfG, 1993, 88 BVerfGE 203, ambos traducidos en SchwABE, Jürgen, Jurisprudencia del Tribunal Constitucional Federal Alemán: Extractos de las Sentencias más Relevantes Compiladas por Jürgen Schwabe, traducción: Marcela Anzola Gil y Emilio Maus Ratz. Konrad Adenauer Stiftung, Programa Estado de Derecho para Latinoamérica, Berlín - México, D.F., 2009, pp. 114-121 \& 121-140. En ocasiones estas sentencias utilizan en el lenguaje original las expresiones Kind (niño) o ungeborenen Kindes (niño no nacido) para referirse al no nacido.

150 Ibíd. pp. 128 \& 129. Esta Corte también exigió al Estado tomar medidas de acción positivas que incentivaran a la madre a dar a luz a su hijo. Después de hacerlo, analizó el resto del proyecto de ley que estaba siendo analizado en abstracto, y determinó qué excepciones al derecho a la vida serían permisibles según la Ley Fundamental Alemana. Sin embargo, al contrario de lo que sería permitido en la $\mathrm{CADH}$, la Corte Federal Alemana consideró como admisibles un gran rango de excepciones a la penalización del aborto. Probablemente esta decisión fue influenciada por la falta de una referencia explícita al no nacido en la Ley Fundamental Alemana.
} 
la realización de abortos. ${ }^{151}$ Esta afirmación es digna de atención, pues la Ley Fundamental Alemana no hace referencia explícita al no nacido ni a la protección de su vida mediante la ley, temas que la Convención Americana menciona expresamente. La posición de la Corte Constitucional Federal Alemana contraría la de aquellos que consideran que "legislaciones de aborto liberales no predicen una mayor incidencia de abortos, y del mismo modo, legislaciones de aborto altamente restrictivas no están asociadas con una baja incidencia de abortos". ${ }^{152} \mathrm{Sin}$ embargo, la precisión de esta última consideración no hace menos convincente la afirmación de la Corte Constitucional Alemana, ya que, si bien es cierto que legislaciones restrictivas en materia de aborto no coincidirán necesariamente con bajas tasas de terminaciones del embarazo, ello no significa que la prohibición del aborto no tenga efectos en la reducción de las tasas de aborto. En efecto, la evidencia apunta a que las legislaciones que restringen el aborto sí inciden en la reducción el número de terminaciones del embarazo. ${ }^{153}$

Una normativa nacional que no prohíba explícitamente las violaciones al derecho a la vida del no nacido -sin perjuicio de las excepciones cubiertas por la expresión "en general"- parecería ser inadmisible en el sistema interamericano.

\footnotetext{
${ }^{151}$ En varios casos la Corte Interamericana se ha referido al efecto disuasivo de las penas.

152 Sedgh, Gilda et al., Guttmacher Institute, y Åhman, Elisabeth y Shah, Iqbal H., World Health OrGanization, "Induced Abortion: Estimated Rates and Trends Worldwide", Lancet 370, 2007, p. 1343. Traducido libremente por el autor. Esta afirmación se basa en una simple comparación de las tasas de aborto entre países con y sin estas leyes.

${ }^{153}$ En efecto, para analizar adecuadamente el efecto de leyes de aborto en la reducción del número de terminaciones del embarazo, no se puede simplemente comparar países con y sin leyes restrictivas del aborto. Las comparaciones entre países con y sin este tipo de regulaciones debe hacerse -en cuanto sea posible- en condiciones de ceteris paribus, es decir, manteniendo las demás variables constantes. Un estudio que no se realice en tales condiciones podría no prestar suficiente atención a otros factores con incidencia en el resultado del análisis. Por ello, para entender los efectos de las leyes de aborto restrictivas, un estudio debiera comparar países o regiones con posiciones contrarias en materia de aborto, pero con condiciones similares en otras áreas. Si una comparación es llevada a cabo en estos términos, pareciera que regiones con leyes restrictivas en materia de aborto tienen menores tasas de terminaciones de embarazos. Por ejemplo, si se distingue entre las regiones según su nivel de desarrollo socioeconómico (muy a grandes rasgos, debido a la poca información del estudio que se toma como base), resulta que aquellas regiones con legislaciones de aborto liberales parecen tener mayores tasas de abortos. Esto sucede si se compara Europa Oriental con Sudamérica, o África Central con el Sudeste Asiático (haciendo abstracción de los países desarrollados de esta última región), o, incluso, Europa Occidental con Estados Unidos y Canadá (donde los motivos según los cuales se permite el aborto no son sustancialmente distintos, pero sí lo son los plazos límite para la realización de tal acto). Ver Ibíd. en 1342. Algo similar puede observarse en una publicación menos reciente. HENSHAW, Stanley, SINGH, Susheela \& HAAS, Taylor, GUtTMACHER InSTITUTE, "The Incidence of Abortion Worldwide". International Family Planning Perspectives 25, 1999, pp. S30, S31. Una explicación tentativa de la influencia del desarrollo socioeconómico en las tasas de interrupciones del embarazo sería que el problema social del aborto no puede ser enfrentado sólo a través de legislaciones restrictivas, sino que requiere también de otras medidas, como una mayor educación, y un adecuado soporte a las madres embarazadas. Estas medidas serán probablemente mejor provistas en regiones con un desarrollo sociocultural mayor.
} 
La primera razón para afirmar esto es el derecho a la igual protección, establecido en el artículo 24 de la Convención, que exigiría el uso de los mismos medios de protección para las personas nacidas y no nacidas. Asimismo, la Convención se refiere a la protección del nacido y del no nacido en la misma oración, sugiriendo que la protección de ambos tipos de individuos debiera ser otorgada en términos análogos -sin perjuicio de las excepciones cubiertas la expresión "en general" -. Además, una aproximación no prohibitiva a las violaciones al derecho a la vida estaría en contradicción con la jurisprudencia constante de la Corte en este sentido. ${ }^{154}$ Por último, la oposición de los redactores de la Convención a las propuestas para suprimir la referencia a la concepción, y los términos de la discusión según los trabajos preparatorios, sugieren que los redactores de la Convención tenían en mente normas prohibitivas. ${ }^{155}$ En vista de los motivos anteriores, este estudio considera que el mandato de proteger al no nacido por la ley requiere que las legislaciones internas prohíban el aborto, salvo en aqueIlas excepciones permitidas según la expresión "en general". Las excepciones autorizadas por este precepto serán analizadas en la sección siguiente.

\subsection{Tres interpretaciones posibles}

El texto de la Convención establece que la regla general debiera ser la defensa del no nacido, y que la desprotección de la vida desde el momento de la concepción es autorizada sólo en circunstancias excepcionales. ${ }^{156}$ Generalmente esta obligación requerirá que el Estado proteja a la madre de la acción

\footnotetext{
${ }^{154}$ Entre otras cosas, la Corte ha sido bastante consistente en interpretar la Convención como imponiendo al Estado "el deber jurídico de 'prevenir, razonablemente, las violaciones de los derechos humanos, de investigar seriamente con los medios a su alcance las violaciones que se hayan cometido dentro del ámbito de su jurisdicción a fin de identificar a los responsables, de imponerles las sanciones pertinentes y de asegurar a la víctima una adecuada reparación'". Sentencia de Excepción Preliminar, Fondo, Reparaciones y Costas de la CtIDH, González y Otras ("Campo Algodonero") Vs. México, 16 de noviembre de 2009 (ser. C) № 205, párr. 236. Asimismo, ha afirmado que es sumamente importante determinar si el Estado ha permitido que el acto tenga lugar sin tomar las medidas necesarias para prevenirlo o para sancionar a los responsables. Ibíd. Para una crítica de la obligación de sancionar a los responsables establecido por la Corte, ver BASCH, Fernando Felipe, "The Doctrine of the Inter-American Court of Human Rights Regarding State's Duty to Punish Human Rights Violations and Its Dangers". American University International Law Review 23, 2007, pp. 195-229. Incluso si esta obligación de sancionar se redujera sólo a las violaciones graves de la $\mathrm{CADH}$, sería difícil considerar que el extinguir una vida no se halla dentro de esta categoría.

${ }^{155}$ Más aún, ésta podría ser la razón que explique por qué la Convención dispone que la protección del no nacido debe hacerse "por la ley", ya que el principio de legalidad afirma que las sanciones sólo pueden imponerse a través de este tipo de normas. Este principio se halla establecido en el artículo $9^{\circ}$ de la Convención.

${ }^{156}$ De otro modo, la norma pertinente dispondría: " $y$, excepcionalmente, a partir del momento de la concepción".
} 
de terceras personas que podrían dañar a su hijo (v.gr. haciendo que ellas lleven a cabo labores pesadas o afectando su integridad física), y al niño de acciones que pudieran dañarlo. Sin embargo, el artículo 4.1 permite ciertas excepciones a este principio de la protección de la vida. La existencia de excepciones a este derecho parece filosóficamente incoherente con el espíritu de la Convención, pero no lo será, necesariamente, si tales excepciones son interpretadas a la luz de otras disposiciones del Pacto de San José.

$\mathrm{Ni}$ la Convención ni los trabajos preparatorios dejaron muchas pistas claras para resolver cuáles son las excepciones al derecho a la vida permitidas por el Pacto de San José. Sin embargo, cualquier interpretación que se haga al artículo 4.1 debe seguir el principio de ut res magis valeat quam pereat, es decir, debe excluir interpretaciones que tornen superflua la frase "en general, a partir del momento de la concepción". ${ }^{157}$ Por una parte, esto excluirá lecturas que interpreten la frase "en general" de un modo en que sea difícilmente compatible con su sentido literal ordinario, como aquella que hace Rodolfo Barra. Él considera que esta expresión no hace una salvedad al derecho a la vida, sino que buscaría enfatizar que la protección de la ley debe comenzar con la concepción. Él interpreta la expresión "en general" como diciendo "en igualdad de condiciones para todos los casos", solución que parece artificiosa. ${ }^{158}$ Ricardo Bach de Chazal interpreta esta norma en el mismo sentido que Rodolfo Barra. ${ }^{159}$

Por otro lado, el artículo 4.1 también excluye interpretaciones que priven de contenido a la generalidad de la protección desde el momento de la concepción, como sucede con la explicación de Cecilia Medina. Ella parece encontrar en la regulación estadounidense un ejemplo paradigmático de qué es lo que la Convención habría querido consagrar. ${ }^{160}$ Esta interpretación desconoce que, según la Convención, la protección de la vida del niño no nacido debiera ser la regla general, prohibiendo la implementación del aborto libre. Asimismo, esta lectura no toma en cuenta que el mismo artículo 4.1 de la Convención

\footnotetext{
${ }^{157}$ Este principio también es Ilamado del efecto útil, y dispone que "[c]uando un tratado da pie a dos interpretaciones, de las cuales una permite que el tratado surta los efectos adecuados y la otra no, la buena fe y el objeto y fin del tratado requieren que se adopte la primera interpretación". NACIONES UNIDAS, Anuario de la Comisión de Derecho Internacional. Vol. II, Naciones Unidas, Nueva York, 1967, p. 240.

${ }^{158}$ Su interpretación es compartida por Corral Talciani. BARRA, citado en CORRAL, Derecho, cit. nota n. 53, p. 86.

159 BaCh De ChazAl, Ricardo, El Aborto en el Derecho Positivo Argentino El Derecho, Buenos Aires, 2009, p. 199, citado en Tozzı, Piero A., Casillas Padrón, Neydy y Marcilese, Sebastián. "El Aborto en el Derecho Internacional y en la Jurisprudencia Panamericana", El Derecho. Diario de Doctrina y Jurisprudencia 12.837, 19 de septiembre de 2011, p. 4. Estos autores que citan el trabajo de Bach de Chazal comparten su opinión.

${ }^{160}$ Medina, La Convención, cit. nota n. 37, p. 76.
} 
establece que "[n]adie puede ser privado de la vida arbitrariamente", por lo que prohibiría el aborto a pedido.

Teniendo en consideración lo anterior, parece haber sólo tres interpretaciones de la expresión "en general" que no son demostrablemente incompatibles con la norma pertinente de la Convención. Las primeras dos se basan en que los redactores de la Convención no quisieron aceptar la propuesta de los Estados Unidos y Brasil, cuyas legislaciones de la época aceptaban casos muy limitados de aborto. ${ }^{161}$ La primera de estas dos interpretaciones es de Rita Joseph, quien encuentra la clave para interpretar el artículo 4.1 de la Convención en los travaux préparatoires del PIDCP. Ella considera que la adición de la expresión "en general" no buscó ser una solución para permitir a ciertos Estados mantener sus leyes de aborto, sino para expresar que el derecho a la vida debe entenderse, "a grandes rasgos, desde el momento más temprano de existencia o, hablando en forma más práctica, desde el primer conocimiento que se tenga de la existencia del niño por parte de la madre, el doctor y/o el Estado"162

A diferencia de lo que hace Barra, Joseph utiliza la expresión "en general" en su sentido ordinario, esto es, expresando la existencia de excepciones a una regla general. Ella considera, inspirada en lo que se discutió durante la elaboración del PIDCP, ${ }^{163}$ que las razones para agregar la expresión "en general" habrían sido dos, de naturaleza meramente práctica: a) Que es "imposible para el Estado determinar el momento de la concepción y, por tanto, embarcarse en la protección de la vida literalmente desde dicho momento", ${ }^{164}$ y b) Que sería imposible establecer estándares universales a lo largo de asociaciones médicas nacionales y diferentes jurisdicciones legales en materia de protección del no nacido, ya que las legislaciones nacionales están basadas en principios diferentes en esta materia. ${ }^{165}$ Rita Joseph considera que la única

\footnotetext{
${ }^{161}$ Según se dijo, Brasil aceptaba sólo unos pocos supuestos. En Estados Unidos el caso Roe Vs. Wade aún no había sido resuelto. Para una detallada lista de las limitadas normas sobre aborto vigentes en los distintos estados de este último país antes del caso Roe, ver Sentencia de la Corte Suprema de EE.UU., Roe v. Wade, 410 U.S. 113 (1973) nota al pie 2, pp. 118 \& 119, y la nota al pie 37, p. 140 de dicha sentencia.

${ }^{162}$ JOSEPH, Human Rights, cit. nota n. 34, p. 225. Traducido libremente por el autor.

${ }^{163}$ Cfr. A/3764 párr. 112, reimpreso en RamCharan, The Right, cit. nota n. 35, p. 225. Esta discusión siguió a la presentación de una enmienda propuesta por varios países para incluir la frase "a partir del momento de la concepción" (traducido libremente por el autor) en la disposición sobre el derecho a la vida en el PIDCP. Entre estos Estados se encontraba, irónicamente, Brasil.

${ }^{164}$ JOSEPH, Human, cit. nota n. 34, p. 229. Traducido libremente por el autor. Por ejemplo, un Estado no podría ser considerado responsable por aplicar la pena de muerte a una mujer embarazada que desconocía su gravidez.

165 Ibíd.
} 
razón de peso fue la primera. ${ }^{166} \mathrm{El}$ problema con esta interpretación es que se basa principalmente en argumentos esgrimidos en la discusión de un tratado internacional diferente.

Una segunda interpretación basada en el rechazo de la propuesta de Brasil y los Estados Unidos, considera que los redactores de la Convención no quisieron permitir las formas de aborto aceptadas en legislaciones como la brasileña y la estadounidense de aquel entonces. Por ello, afirma que la frase "en general" permite sólo excepciones al derecho a la vida del nasciturus que sean aceptadas en legislaciones que prohíben el aborto directo. ${ }^{167}$ Estos sistemas legales consideran como no sancionables aquellas terminaciones del embarazo que resulten de la aplicación del principio del doble efecto, es decir, los abortos indirectos. ${ }^{168}$ Tales son los abortos producidos como el efecto previsto, pero no deseado, de intervenciones médicas indispensables y proporcionadas en el cuerpo de la madre. Estos abortos no se producen como resultado de una acción que busque dañar directamente al no nacido. Un ejemplo de aborto indirecto puede darse en el caso de una mujer embarazada que requiera inmediatamente de una quimio o radioterapia como el único modo de tratar un cáncer que amenace su vida, tratamiento que probablemente resultará en la muerte del no nacido. Esta situación fue la del caso "Amelia", conocido por la Comisión Interamericana. ${ }^{169}$ Algo similar podría suceder en el caso de un embarazo ectópico. ${ }^{170}$

Sin perjuicio de lo anterior, un sistema donde el aborto esté prohibido es también compatible con reglas penales que disminuyan, o incluso extingan, la responsabilidad criminal para quienes cometen acciones susceptibles de ser sancionadas, como sucede con la aplicación de circunstancias atenuantes. Una

\footnotetext{
${ }^{166}$ Ella afirma que esta segunda razón no habría tenido mucho peso en ese momento, ya que en septiembre de 1948 la Asociación Médica Mundial promulgó la Declaración de Ginebra, que más tarde sería reafirmada unánimemente por la Declaración de Ginebra de 1968. Ella incluía en ese entonces el deber solemne de respetar la vida humana desde el momento de la concepción, y de protegerla según las leyes de la humanidad. Ibíd., 230.

${ }^{167}$ En el caso de Chile, esto es descrito en MiRanda MonteCinos, Alejandro, "El Principio del Doble Efecto y Su Relevancia en el Razonamiento Jurídico", Revista Chilena de Derecho 35, 2008, pp. 510-513. Para un debate en profundidad sobre este principio puede verse WOODWARD, P.A. (Ed.), The Doctrine of Double Effect: Philosophers Debate a Controversial Moral Principle, University of Notre Dame Press, Notre Dame, Indiana, 2001.

${ }^{168}$ Esta afirmación no busca ser una aplicación precisa y exhaustiva del principio del doble efecto en el tema del aborto, pues este principio contiene algunas condiciones en las que este artículo no se explaya, pero que pueden verse en MiRAnDA, "El Principio", cit. nota n. 167, pp. 502 ss.

169 "Amelia", cit. nota n. 132.

${ }^{170}$ Dos interpretaciones diferentes sobre qué permitiría el principio de doble efecto en estas situaciones puede verse en DeVINE, Philip E., "The Principle of Double Effect", The American Journal of Jurisprudence 19, 1974, y KACZOR, Christopher, "Moral Absolutism and Ectopic Pregnancy", Journal of Medicine and Philosophy 26, 2001.
} 
excepción mucho más controvertida a la protección de la vida en países donde el aborto está prohibido, es el caso de legislaciones criminales que consagran un concepto amplio del estado de necesidad. Éstas son a veces usadas por el sistema judicial para absolver a quienes se han procurado un aborto en el contexto de un embarazo que amenace la vida de la madre. ${ }^{171}$ Este último sistema no admite explícitamente el aborto, pero permite que en ciertas ocasiones su realización no sea sancionada.

Tratando de significar un aporte para la actual discusión sobre este tema en Chile, es interesante notar que en ocasiones el debate parlamentario ha traído a colación el aborto indirecto, pensando algunos que dicha práctica no estaría permitida en el país. Este sería un malentendido, pues la doctrina y la práctica médica consideran que la legislación nacional permite la realización de acciones que tengan el efecto indirecto de producir abortos, puesto que tales acciones no tienen el fin de interrumpir un embarazo, cuestión prohibida por el Código Sanitario. ${ }^{172}$ En efecto, si bien la legislación nacional no se refiere expresamente al tema de los abortos indirectos, la redacción del referido Código los permite, ajustándose adecuadamente al ideal prescrito por la Convención Americana.

Una tercera forma de interpretar la Convención es prestando atención sólo al texto del Pacto, sin tener en consideración que la posición de Brasil y los Estados Unidos no fue aceptada. Esta posición verá en la redacción actual del artículo 4.1 un acuerdo político entre los Estados que autorizaban el aborto en ciertos casos, y aquellos que no lo hacían. Como consecuencia, esta interpretación sería compatible con legislaciones estatales que permitan el aborto en forma excepcional, como sucede cuando los embarazos constituyen un peligro real para la vida de la madre, o cuando ellos son el resultado de una violación. Estos fueron los dos casos descritos por el delegado de Brasil al momento de oponerse a la norma correspondiente. Los párrafos siguientes mostrarán que esta tercera interpretación no es convincente.

La interpretación que la Comisión hace de la Convención parece ser similar a esta tercera lectura. ${ }^{173}$ Sin embargo, la Comisión ha considerado, inadecua-

\footnotetext{
171 Según las Naciones Unidas, un ejemplo de ello sería República Dominicana: UnIted Natıons, Abortion Policies: A Global Review. Vol I, United Nations Publicacions, Nueva York, 2001, p. 130. En: http:// www.un.org/esa/population/publications/abortion/index.htm [visitado el 31/01/11].

${ }^{172}$ El art. 119 del Código Sanitario dispone: “No podrá ejecutarse ninguna acción cuyo fin sea provocar un aborto".

${ }^{173}$ Debe recordarse que la Comisión ha aplicado la Convención sólo en casos como el de Paulina Ramírez, Fertilización in Vitro, y en documentos generales como informes de país, ya que en el caso Baby Boy la Comisión sólo aplicó la Declaración Americana, no la Convención. El asunto de "Amelia" en Nicaragua carece de importancia para estos efectos, ya que se refiere al caso de un aborto indirecto, además de tratarse sólo de una medida cautelar. Gros también compartiría esta tercera interpretación. GROS, La Convencion, cit. nota n. 53, p. 228.
} 
damente, que los Estados están obligados a establecer algunas excepciones al derecho a la vida. Al hacerlo, olvida que la expresión "en general" habría sido establecida, a lo más, como una válvula de escape, no como un mandato. Ninguna interpretación del artículo 4.1 permitiría considerar el aborto como un derecho en el sistema interamericano, pues incluso la interpretación más flexible de esta norma consideraría al aborto sólo como una excepción al derecho a la vida.

\subsection{Interpretación más convincente}

Las tres interpretaciones recién expuestas no son demostrablemente incompatibles con el texto del artículo 4.1 de la Convención. Sin embargo, la segunda solución parece ser la más convincente a la luz de las demás disposiciones del Pacto, considerado como un todo. La primera razón por la cual esta interpretación parece más convincente, es porque tiene en consideración, junto con la lectura de Rita Joseph, que la propuesta de Brasil y los Estados Unidos fue rechazada, mientras que la tercera interpretación parece estar ciega frente a este hecho. En efecto, el rechazo de tal propuesta sólo puede significar que las naciones americanas no querían consentir, precisamente, en aquellas excepciones que eran autorizadas por tales Estados, las que ya eran bastante limitadas. Entre las dos interpretaciones que tienen en cuenta este hecho, aquella de Rita Joseph no parece muy convincente, ya que se basa principalmente en los trabajos preparatorios de una convención de derechos humanos distinta.

La existencia de disposiciones similares a las de Brasil y Estados Unidos en otras naciones americanas no sirve para argumentar que tales naciones quisieran permitir esos mismos casos de aborto. ${ }^{174}$ En efecto, los tratados de derechos humanos suelen reflejar la intención de los Estados partes de modificar sus leyes de acuerdo con lo establecido en tales instrumentos. Esta es la razón por la que el artículo segundo de la Convención establece que los Estados deben adaptar su legislación interna a las normas del Tratado. Por ejemplo, varios representantes estatales votaron a favor de la norma que establecía la igualdad de derechos para los niños nacidos fuera y dentro del matrimonio, no obstante reconocer explícitamente que la legislación de sus países estaba en contradicción con ella. ${ }^{175}$ Debe también recordarse que los redactores decidieron mantener la referencia al momento de la concepción "por razones de principio". ${ }^{176}$

\footnotetext{
${ }^{174}$ Lamentablemente no es posible saber si los Estados que tenían esas excepciones votaron por rechazar esta referencia al momento de la concepción. Esta falta de detalles puede observarse en: SECRETARía General, cit. nota n. 63, p. 160.

175 Ibíd. pp. 227-229.

${ }^{176}$ General Secretariat, Anuario Interamericano, cit. nota n. 28, p. 97.
} 
Otro motivo por el cual la segunda interpretación parece más plausible que la tercera, es la distinción entre protección y respeto consagrada en la primera y segunda oraciones del artículo 4.1. El Pacto de San José establece que habrá casos en los que el derecho a la vida no será protegido, pero no provee excepciones al respeto del derecho a la vida. Esta redacción es enigmática, ya que ambos conceptos suelen ir de la mano. No es fácil entender cómo se puede respetar un derecho sin protegerlo. No obstante, este enigma puede resolverse si la segunda interpretación es adoptada. En efecto, tal lectura no le faltará el respeto al nasciturus, ya que no permite acciones dirigidas directamente en su contra. Sin embargo, al mismo tiempo admite situaciones en que la protección de la vida del nasciturus no se garantice, ya que el no nacido puede perecer cuando la madre requiera someterse a ciertos tratamientos necesarios para salvar su propia vida.

Una razón adicional por la que la segunda interpretación es más convincente, es que está de acuerdo con el derecho a la igual protección de la ley, establecido en el artículo 24. Tal norma dispone: "Todas las personas son iguales ante la ley. En consecuencia, tienen derecho, sin discriminación, a igual protección de la ley". Esta disposición es aplicable al no nacido, ya que, según fue probado previamente, el nasciturus es considerado una persona según el texto de la Convención. Así, una interpretación coherente del Tratado Americano debiera entender que el derecho a la vida del no nacido se encuentra en igualdad de condiciones con el de su madre, por lo que sólo serían permisibles aquellas excepciones que no involucren un ataque directo a su persona. Una interpretación que permita acciones destinadas a acabar directamente con la vida del no nacido, incluso si éstas se realizan después de equilibrar los intereses de la madre con los del concebido, iría en contra de lo dispuesto en el artículo 24 de la Convención. ${ }^{177}$ Sólo una acción que no atente directamente en contra de la vida del no nacido sería admisible como excepción a la protección de la vida según el artículo 4.1 del Pacto de San José de Costa Rica.

La segunda interpretación no es sólo más coherente con el texto e historia de la Convención, sino que también deja menos temas abiertos para una futura interpretación que la tercera lectura. El principal tema que la tercera interpretación deja abierto a lecturas posteriores es qué tipo de abortos serían excepcionalmente permitidos, y cómo se les determinaría. Sería posible argumentar que estos abortos son aquellos referidos por el delegado de Brasil, pero incluso esas limitadas causales de aborto darían lugar a las inconsistencias ya referidas (v.gr.: falta de respeto por la vida, inequidad, etc.). Asimismo, el establecimiento de

177 Más aún si el nasciturus es abortado por ser discapacitado, ya que tal acción iría en contra de la pre-
misa de que todos los seres humanos - sin importar su condición física o mental- tienen igual dignidad
humana. Cfr. DAvis, Alison "Right to Life of Handicapped". Journal of Medical Ethics 9, 1983, p. 181. 
excepciones a la protección del derecho a la vida, sin un mecanismo dirigido a abolirla gradualmente, como se hizo en la norma que trata de la pena de muerte, parece filosóficamente incoherente en el contexto de la Convención. ${ }^{178}$

Otro asunto que debiera ser elucidado en caso de adoptarse la tercera interpretación, es si la frase "en general" estaría destinada a otorgar una escapatoria política sólo a los Estados que ya contaban con una legislación que permitía el aborto, o si también se habría dirigido a aquellos países que no permitían el aborto en ese momento. En este último tema, atendido que los travaux prépratoires no dan pistas al lector, podrían usarse dos reglas interpretativas que Ilevarían a resultados opuestos. Si se sigue la regla de que al intérprete no le es lícito distinguir donde el legislador no ha distinguido, esta excepción podría también ser aplicada por aquellos Estados que prohibían el aborto al momento de elaborarse la Convención. En cambio, si el lector aplica el principio de que las excepciones a una regla general deben ser leídas restrictivamente -especialmente si excluyen de la aplicación de un tratado de derechos humanos-, el resultado sería el opuesto. ${ }^{179}$

\section{CONCLUSIÓN}

El caso Xákmok Kásek, que motivó este trabajo, fue el primero en el que la Corte de las Américas se vio enfrentada directamente con el tema del no nacido. En tal caso, el tribunal interamericano prefirió no resolver dicho asunto, alegando que ni la Comisión ni los representantes habrían presentado suficientes argumentos jurídicos. Esta negativa a decidir el tema del no nacido puede haberse debido a su naturaleza tan controversial. Sin embargo, este camino seguido por la Corte no fue adecuado, ya que un tribunal de Derecho tiene el deber de interpretar las normas que son esgrimidas ante él. Esto es especialmente así en el caso de la Corte Interamericana, que hace un uso extenso del principio del iura novit curia.

Para resolver este caso, el Tribunal debió haber recurrido a la Convención. Ésta declara que el nasciturus tiene derecho a la vida, a pesar de que este derecho no estará siempre protegido por ley. El Pacto de San José llega hasta a reconocerle personalidad al no nacido, cuestión que sería parcialmente reconocida por la Comisión para efectos procesales. La negativa postura de la Comisión frente a la prohibición de acciones contra el nasciturus que sean ampliamente aceptadas en América (como sucede con el caso de las fecundaciones in vitro), no es

\footnotetext{
${ }^{178} \mathrm{El}$ art. 4.2 in fine dispone: "Tampoco se extenderá su aplicación [de la pena de muerte] a delitos a los cuales no se la aplique actualmente", y el art. 4.3 establece que "[n]o se restablecerá la pena de muerte en los Estados que la han abolido".

${ }^{179}$ Cfr. Schwabe, Jurisprudencia, cit. nota n. 149, p. 116 (c).
} 
un obstáculo para la afirmación previa. Además, esta lectura que la Comisión hace de la Convención no vincula a la Corte. En efecto, esta última ha estado en desacuerdo con las interpretaciones de la Comisión en varias ocasiones.

El Pacto de San José resuelve lo que en algunos sistemas jurídicos ha sido entendido como un choque entre los derechos del no nacido y de la mujer embarazada. Lo hace porque "el derecho a la vida es fundamental en la Convención Americana, por cuanto de su salvaguarda depende la realización de los demás derechos". ${ }^{180}$ Según la Convención, el derecho a la vida pesaría más que otros derechos que estén en conflicto con éste. No obstante ello, el texto del derecho a la vida en la Convención no es absolutamente claro, ya que permite excepciones, sin señalar cuáles son éstas. Es por ello que este estudio buscó descifrar el sentido de la norma que declara el derecho a la vida, en la parte referida al no nacido.

Existen tres interpretaciones no demostrablemente incompatibles con el texto de la Convención, acerca de las excepciones permitidas en dicho tratado al derecho a la vida del nasciturus. Entre ellas, la más persuasiva es la que considera que la Convención permitiría sólo los abortos indirectos, es decir, las terminaciones del embarazo producidas como el efecto previsto, pero no deseado, de intervenciones médicas indispensables y proporcionadas en el cuerpo de la madre. Las razones principales para afirmar esto se desprenden del texto del artículo 4.1, del análisis del Pacto de San José como un todo, y de la historia de la Convención. Ejemplo de éstas sería una radioterapia requerida como el único modo de enfrentar un cáncer que amenace la vida de una mujer embarazada, tratamiento que probablemente resultará en la muerte del no nacido. Casos como éstos no se encuentran explícitamente descritos en la legislación chilena. Sin embargo, la redacción del Código Sanitario los permite, haciendo que el ordenamiento jurídico nacional se ajuste al ideal prescrito por la Convención Americana.

Por último, volviendo al caso que motivó la realización de este estudio, puede notarse que ninguna de las interpretaciones descritas en este trabajo daría pie para considerar las muertes causadas por la negligencia estatal como excepciones permitidas al derecho a la vida según el Pacto de San José. Por este motivo, la solución del caso Xákmok en materia de los no nacidos era suficientemente sencilla: atendido que la Convención dispone que el Estado debe pagar una justa reparación a la parte lesionada, ${ }^{181}$ la Corte debió haber

\footnotetext{
${ }^{180}$ Sentencia de Excepciones Preliminares, Fondo, Reparaciones y Costas de la CtIDH, "Instituto de Reeducación del Menor" Vs. Paraguay, 2 de septiembre de 2004 (Ser. C) N 112, párr. 156 (se omiten las notas al pie). Cfr. Caso Xákmok, párr. 186.

${ }^{181}$ Art. 63.1 CADH.
} 
concedido la indemnización solicitada por los miembros de la Comunidad Indígena, pues el Estado no otorgó el cuidado y protección requeridos por los niños antes de su nacimiento.

\section{Biblografía}

\section{Libros y artículos}

Abramson, Bruce, Violence Against Babies: Protection of Pre- and Post-Natal Children Under the Framework of the Convention on the Rights of the Child. Versión Revisada. World Family Policy Center, Utah, 2006.

Alston, Philip, "The Historical Origins of the Concept of 'General Comments' in Human Rights Law", en The International Legal System in Quest of Equity and Universality / L'Ordre Juridique International, un Système en Quête D'Équité et D'Universalité: Liber Amicorum Georges Abi-Saab, Kluwer Law International, 2001.

-"The Unborn Child and Abortion Under the Draft Convention on the Rights of the Child", Human Rights Quarterly 12, 1990.

Arato, Julian, "Subsequent Practice and Evolutive Interpretation: Techniques of Treaty Interpretation over Time and Their Diverse Consequences". The Law and Practice of International Courts and Tribunals, 9, 2010.

$\mathrm{BASCH}$, Fernando Felipe, "The Doctrine of the Inter-American Court of Human Rights Regarding State's Duty to Punish Human Rights Violations and Its Dangers" American University International Law Review 23, 2007.

BAZÁN, Víctor, "Las Reservas a los Tratados Internacionales sobre Derechos Humanos, con Particular Énfasis en el Efecto de Aquellas Respecto de la Entrada en Vigencia de la Convención Americana sobre Derechos Humanos". 2000. lus et Praxis 6.

Bordalí Salamanca, Andrés y Zúñ̃aga Añazco, Yanira, "Análisis del Fallo del Tribunal Constitucional sobre la Píldora del Día Después" Anuario de Derechos Humanos 5, 2009.

Corral Talciani, Hernán, Derecho Civil y Persona Humana: Cuestiones Debatidas, LexisNexis, Santiago, 2007.

Davidson, Scott, "The Civil and Political Rights Protected in the Inter-American Human Rights System", en The Inter-American System of Human Rights, O.U.P., Oxford, 1998.

Davis, Alison "Right to Life of Handicapped". Journal of Medical Ethics 9, 1983.

De Oliveira Baracho, José Alfredo, "A Prática Jurídica no Domínio da Proteção Internacional dos Direitos do Homem (A Convenção Européia dos Direitos do Homem)", en Corte Interamericana de Derechos Humanos. Liber Ami- 
corum Héctor Fix-Zamudio. Vol. I, Ed. Secretaría de la Corte Interamericana de Derechos Humanos, 1998.

Devine, Philip E., "The Principle of Double Effect", The American Journal of Jurisprudence 19, 1974.

DíAz de Valdés J., José Manuel, "Análisis Crítico de la Jurisprudencia de la Corte Europea de Derechos Humanos sobre el Estatus del No Nacido en la Convención Europea de Derechos Humanos" 2008. Actualidad Jurídica 18.

Faúndez Ledesma, Héctor, El Sistema Interamericano de Protección de los Derechos Humanos: Aspectos Institucionales y Procesales Instituto Interamericano de Derechos Humanos, San José, 2004.

Fitzmaurice, Malgosia, "The Practical Working of the Law of Treaties", en International Law. $2^{\text {a }}$ ed., O.U.P., Oxford, 2006.

Ford, Allison, "Mexico City Legalizes Abortion" 2010. Law and Business Review of the Americas 16.

General Secretariat of the Organization of American States, Anuario Interamericano de Derechos Humanos 1968 / Inter-American Yearbook on Human Rights 1968. Secretariat of the Inter-American Commission on Human Rights, Washington D.C., 1973.

Gerber, Rudy J. 1970. "Abortion: Two Opposing Legal Philosophies", The American Journal of Jurisprudence, 15.

Gros Espiell, Héctor, La Convención Americana y La Convención Europea de Derechos: Análisis Comparativo Editorial Jurídica de Chile, Santiago, 1991.

Henshaw, Stanley, Singh, Susheela \& Haas, Taylor, Guttmacher Institute, "The Incidence of Abortion Worldwide" International Family Planning Perspectives 25, 1999.

Htun, Mala, Sex and the State: Abortion, Divorce, and the Family Under Latin American Dictatorships and Democracies. Cambridge University Press, Cambridge, 2003.

Jayawickrama, Nihal, The Judicial Application of Human Rights Law, Cambridge University Press, Cambridge, 2002.

JosepH, Rita, Human Rights and the Unborn Child, Martinus Nijhoff Publishers, Leiden, 2009.

KaCzOR, Christopher, "Moral Absolutism and Ectopic Pregnancy", Journal of Medicine and Philosophy 26, 2001.

KUHSE, Helga y SInger, Peter, Should the Baby Live? The Problem of Handicapped Infants Gregg Revivals, Aldershot, 1985.

Liscano, Carlos, Conversaciones con Tabaré Vázquez, Colihue, Buenos Aires, 2004. 
Mahoney, Paul, "Judicial Activism and Judicial Self-Restraint in the European Court of Human Rights: Two Sides of the Same Coin" Human Rights Law Journal 11, 1990.

Medina Quiroga, Cecilia, La Convención Americana: Vida, Integridad Personal, Libertad Personal, Debido Proceso y Recurso Judicial Universidad de Chile, Facultad de Derecho, Centro de Derechos Humanos, 2003.

Mills, Eithne y McConviLL, James "The 2002 Irish Abortion Referendum: A Question of Constitutionalism and Conscience", European Journal of Law Reform 4, 2002.

Miranda Montecinos, Alejandro, "El Principio del Doble Efecto y Su Relevancia en el Razonamiento Jurídico", Revista Chilena de Derecho 35, 2008.

Monroy Cabra, Marco Gerardo, "Derechos y Deberes Consagrados en la Convención Americana sobre Derechos Humanos 'Pacto de San José de Costa Rica'" en La Convención Americana sobre Derechos Humanos, Ed. Secretaría General OEA, Washington D.C., 1980.

Montalvo, Andrés E., "Reservations to the American Convention on Human Rights: A New Approach" 2001. American University International Law Review 16.

Moreno Carrasco, Francisco y Rueda García, Luis, Código Penal de El Salvador Comentado. Vol. I, Consejo Nacional de la Judicatura, S.D.

NACIONES UNIDAS, Anuario de la Comisión de Derecho Internacional Vol. II, Naciones Unidas, Nueva York, 1967.

Neuman, Gerald L., "Import, Export and Regional Consent in the Inter-American Court of Human Rights", European Journal of International Law 19, 2008.

Orakhelashvil, Alexander, The Interpretation of Acts and Rules in Public International Law. O.U.P., Oxford, 2008.

Palacios Zuloaga, Patricia, "La Aplicabilidad del Derecho a la Vida al Embrión o Feto en la Jurisprudencia Internacional", Anuario de Derechos Humanos 1, 2005.

Pasqualucci, Jo M., The Practice and Procedure of the Inter-American Court of Human Rights Cambridge University Press, Cambridge, 2003.

RamCharan, B. G. (Ed.), The Right to Life in International Law, Martinus Nijhoff Publishers, Dordrecht, 1985.

Rodríguez Rescia, Víctor, Las Sentencias de la Corte Interamericana de Derechos Humanos: Guía Modelo para su Lectura y Análisis, Instituto Interamericano de DD.HH., San José, 2009.

Schabas, William A., "Canadian Ratification of the American Convention on Human Rights", Netherlands Quarterly of Human Rights, 16, 1998. 
SCHwABE, Jürgen, Jurisprudencia del Tribunal Constitucional Federal Alemán: Extractos de las Sentencias más Relevantes Compiladas por Jürgen Schwabe, traducción: Marcela Anzola Gil y Emilio Maus Ratz, Konrad Adenauer Stiftung, Programa Estado de Derecho para Latinoamérica, Berlín - México, D.F., 2009.

Secretaría General de la Organización de los Estados Americanos, Conferencia Especializada Interamericana sobre Derechos Humanos: Actas y Documentos, OEA/Ser.K/XVI/1.2, San José, Costa Rica, 7-22 de noviembre de 1969. Secretariat of the Inter-American Commission on Human Rights, Washington D.C., 1973. En http://www.corteidh.or.cr/tablas/15388.pdf [visitado el 30/01/11].

Sedgh, Gilda et al., Guttmacher Institute, y Åhman, Elisabeth y Shah, Iqbal H., World Health Organization, "Induced Abortion: Estimated Rates and Trends Worldwide", Lancet 370, 2007.

SHelton, Dinah. "Abortion and the Right to Life in the Inter-American System:

The Case of 'Baby Boy'", Human Rights Law Journal 2, 1981.

Shorter Oxford Eglish Dictionary, 6a ed., Vol. I, 2007.

TANner, Lauri R. "Interview with Judge Antônio A. Cançado Trindade, InterAmerican Court of Human Rights", Annual Survey of International and Comparative Law XVI, 2010.

The Compact Edition of the Oxford English Dictionary, Vol. I, 1971.

Tozzı, Piero A., Casillas Padrón, Neydy y Marcilese, Sebastián. "El Aborto en el Derecho Internacional y en la Jurisprudencia Panamericana", El Derecho. Diario de Doctrina y Jurisprudencia 12.837, 19 de septiembre de 2011.

United Nations, Abortion Policies: A Global Review, Vols. I \& II, United Nations Publications, Nueva York, 2001.

Vivanco Martínez, Ángela, "La Píldora del Día Después", Revista Chilena de Derecho, 35, 2008.

Woodward, P.A. (Ed.), The Doctrine of Double Effect: Philosophers Debate a Controversial Moral Principle, U. of Notre Dame Press, Notre Dame, Indiana, 2001.

Sentencias y documentos sobre asuntos contenciosos

Demanda de la CmIDH ante la Corte Interamericana De Derechos Humanos, caso Comunidad indígena Xákmok Kásek del pueblo Enxet-Lengua y sus miembros (Caso 12.420) contra la República del Paraguay, 3 de julio de 2009.

Informe de la CmIDH, Admisibilidad, James Demers, Canadá, № 85/06, Petición 225-04, 2006. 
Fondo, Gretel Artavia Murillo y Otros (Fertilización in vitro), Costa Rica, № 85/10, Caso 12.361, 2010. En: http://www.asamblea.go.cr/ Centro_de_informacion/biblioteca/Docum entos\%20compartidos/TA-FIV/ Costa\%20Rica/l85-10.pdf [visitado el 08/09/11].

1981.

, Fondo, Estados Unidos de América, № 23/81, Caso 2141,

\section{$\mathrm{CmIDH}$.}

Medida Cautelar, "Amelia", Nicaragua, MC N 43/10, 2010

Solución Amistosa, Paulina del Carmen Ramírez Jacinto, México, N²1/07, Petición 161-02, 2007.

Opinión Consultiva, CtIDH, artículo 55 de la Convención Americana sobre Derechos Humanos, 29 de septiembre de 2009 (Ser. A) 20/09.

El Derecho a la Información sobre la Asistencia Consular en el Marco de las Garantías del Debido Proceso Legal, 1 de octubre de 1999 (Ser. A) 16/99.

El Efecto de las Reservas sobre la Entrada en Vigencia de la Convención Americana sobre Derechos Humanos (arts. 74 y 75), 24 de septiembre de 1982 (ser. A) 2/82.

Interpretación de la Declaración Americana de los Derechos y Deberes del Hombre en el Marco del Artículo 64 de la Convención Americana sobre Derechos Humanos, 14 de julio de 1989 (Ser. A) 10/89.

, La Colegiación Obligatoria de Periodistas (arts. 13 y 29 Convención Americana sobre Derechos Humanos), 13 de noviembre de 1985 (Ser. A) 5/85.

Restricciones a la Pena de Muerte (arts. 4.2 y 4.4 Convención Americana sobre Derechos Humanos), 8 de septiembre de 1983 (Ser. A) 3/83.

Sentencia de Excepción Preliminar, Fondo Reparaciones y Costas de la CtIDH, Boyce y otros Vs. Barbados, 20 de noviembre de 2007, (Ser. C) № 169.

, González y Otras ("Campo Algodonero") Vs. México, 16 de noviembre de 2009 (ser. C) № 205.

\section{C) $\mathrm{N}^{\circ} 207$.}

Usón Ramírez Vs. Venezuela, 20 de noviembre de 2009 (ser.

Sentencia de Fondo, CtIDH, Villagrán-Morales y Otros Vs. Guatemala (Niños de la Calle), 19 de noviembre de 1999 (Ser. C) Nº3.

Sentencia de Fondo, Reparaciones y Costas de la CtIDH, Hermanos GómezPaquiyauri Vs. Perú, 8 de julio de 2004 (ser. C) N 110. Baena et al. Vs. Panamá, 2 de febrero de 2001, (Ser. C) № 72. Comunidad Indígena Xákmok Kásek Vs. Paraguay, 24 de agosto de 2010 (Ser. C) № 214. 
$\mathrm{N}^{\circ} 123$.

Caesar Vs. Trinidad y Tobago, 11 de marzo de 2005 (ser. C) (ser. C) $\mathrm{N}^{\circ} 120$. Hermanas Serrano Cruz Vs. El Salvador, 1 de marzo de 2005 Hilaire, Constantine y Benjamin y otros Vs. Trinidad y Tobago, 21 de junio de 2002 (ser. C) Nº 94.

(ser. C) $\mathrm{N}^{\circ} 160$.

Sentencia de la Corte Constitucional (Colombia), C-355/06, 10 de mayo de 2006. En: http://www.corteconstitucional.gov.co/relatoria/2006/C-355-06. htm [visitado el 07/05/2011].

Sentencia de la Corte Suprema (Costa Rica), Sala Constitucional, 15 de marzo de 2000, Sentencia: 02306, Expediente: 95-001734-0007-CO. En: http://200.91.68.20/scij/busqueda/ju risprudencia/jur_repartidor.asp?para $\mathrm{m} 1=\mathrm{XYZ} \&$ param2 $=1 \& \mathrm{nValor} 1=1 \& \mathrm{nValor} 2=128218 \& \mathrm{strTipM}=\mathrm{T} \& \mid$ Resulta do=10 [visitado el 17/07/11].

Sentencia de la Corte Suprema (EE.UU.), Gonzales Vs. Carhart, 550 U.S. 124 (2007).

, Roe v. Wade, 410 U.S. 113 (1973).

Planned Parenthood of Southeastern Pa. Vs. Casey, 505 U.S.

833 (1992).

Sentencia del Excmo. Tribunal Constitucional que Acoge Parcialmente el Requerimiento de Inconstitucionalidad (Chile), 18 de abril de 2008, Sentencia 740-07-CDS.

Sentencia del Tribunal Constitucional (Perú), 16 de octubre de 2009, Exp. Nº. 02005-2009-PA/TC. En: http://www.tc.gob.pe/jurisprudencia/2009/020052009-AA.html [visitado el 24/10/11].

Sentencia del Tr. Eur. D.H., Johnston and Others v. Ireland, 1986, 112 (Ser. A). Tysiac v. Poland, 2007, App. N 5410/03. A, B \& C v. Ireland, 2010, App. N²5579/05. Belilos v. Switzerland, 132 Eur. Ct. H.R. (Ser. A) (1988). Loizidou v. Turkey 310 Eur. Ct. H.R. (ser. A) (1995).

Sentencia que Declara Inadmisibilidad, CtIDH, Asunto de Gallardo, Viviana y Otras, 13 de noviembre de 1981, (Ser. A) Nº G101/81.

\section{Tratados y documentos internacionales}

Carta de la Organización de los Estados Americanos.

Comité de DD.HH. de las Naciones Unidas, General Comment № 24: Issues relating to reservations made upon ratification or accession to the Covenant 
or the Optional Protocols thereto, or in relation to declarations under article 41 of the Covenant, 11 de abril de 1994.

$\mathrm{CmIDH}$, Tercer Informe sobre la Situación de los Derechos Humanos en Colombia, OEA/Ser.L/V/II.102 Doc. 9 rev. 1, 26 de febrero de 1999. Quinto Informe sobre la Situación de los Derechos Humanos en Guatemala, OEA/Ser.L/V/II.111, doc. 21 rev., 6 de abril de 2001. Acceso a Servicios de Salud Materna desde una Perspectiva de Derechos Humanos, OEA/Ser.L/V/II, Doc. 69, 7 de junio de 2010. Observaciones de la Comisión Interamericana de Derechos Humanos sobre su visita a Haití en abril de 2007, OEA/Ser.L/V/II.131, doc. 36, 2 de marzo de 2008. Informe Anual de la comisión Interamericana de Derechos Humanos 2006, OEA/Ser.L/V/II.127, Doc. 4 rev. 1, 3 de marzo de 2007. Acceso a la Justicia para las Mujeres Víctimas de Violencia en las Américas, OEA/Ser.L/V/II, Doc. 68, 20 de enero de 2007. Informe Anual de la Comisión Interamericana de Derechos Humanos 1992-1993, OEA/Ser./L/V/II.83, doc. 14, 12 de marzo de 1993. Lineamientos para la Elaboración de Indicadores de Progreso en Materia de Derechos Económicos, Sociales y Culturales, OEA/Ser.L/V/ II.132, Doc. 14, 19 de julio de 2008.

Convención Americana sobre Derechos Humanos (1969).

Convención de Viena sobre el Derecho de los Tratados (1969).

Convención Interamericana para Prevenir y Sancionar la Tortura (1985).

Convención Interamericana para Prevenir, Sancionar y Erradicar la Violencia contra la Mujer (1994).

Convención sobre los Derechos del Niño (1989).

Convenio Europeo para la Protección de los Derechos Humanos y de las Libertades Fundamentales (1950).

CtIDH, Reglamento de la Corte Interamericana de Derechos Humanos (2009).

Declaración Americana de los Derechos y Deberes del Hombre (1948).

OEA, Estatuto de la Comisión Interamericana de Derechos Humanos (1979).

Pacto Internacional de Derechos Civiles y Políticos (1966).

Protocolo Adicional a la CADH en Materia de Derechos Económicos, Sociales y Culturales (1988).

Protocolo a la CADH Relativo a la Abolición de la Pena de Muerte (1990).

Legislación y otros documentos oficiales

Código Sanitario (Chile) (1931). 
Códigos Penales de Brasil (1940), Chile (1874), El Salvador (1997), Honduras (1983) y Nicaragua (2007).

Constitución Política de la Constitución Política del Estado Libre y Soberano de Nayarit (1918).

Constituciones políticas de las repúblicas de Ecuador (2008), El Salvador (1992), Guatemala (1985), República Dominicana (2010), Paraguay (1992) y Perú (1993).

Gobierno de Nicaragua. Instituto Nacional de Estadísticas y Censo, VIII Censo de Población y IV de Vivienda, 2005: Población: Características Generales. Gobierno de Nicaragua, S.D., 2006.

Ley № 20.120 (Chile), "Sobre la Investigación Científica en el Ser Humano, su Genoma, y Prohíbe la Clonación Humana", 22 de septiembre de 2006.

Ley N²0.418 (Chile), "Fija Normas sobre Información, Orientación y Prestaciones en Materia de Regulación de la Fertilidad", 28 de enero de 2010.

Ley $N^{\circ} 603$ (Nicaragua), del 26 de octubre de 2006, Ley de Derogación al Artículo 165 del Código Penal Vigente, La Gaceta, Diario Oficial [L.G.], 17 de noviembre de 2006.

Presidencia de la República Oriental del Uruguay, Comunicación Dirigida al Señor Presidente de la Asamblea General, 14 de noviembre de 2008. En: http://www.presidencia.gub.uy/_Web/proyectos/2008/11/s511_00001.PDF [visitado el 29/01/11].

The Senate, Standing Senate Committee on Human Rights, Enhancing Canada's Role in the OAS: Canadian Adherence to the American Convention on Human Rights. S.D., 2003. En: http://www.parl.gc.ca/37/2/parlbus/commbus/senate/ com-e/huma-e/rep-e/rep04may03-e.pdf [visitado el 29/01/11]. 